\title{
Migration and Detention:
}

Mapping the International Legal Terrain

A Global Detention Project Working Paper

By Isabel Ricupero and Michael Flynn

November 2009 


\section{Migration and Detention: Mapping the International Legal Terrain}

A Global Detention Project Working Paper

By Isabel Ricupero and Michael Flynn*

November 2009

\section{Table of Contents}

\section{Introduction}

Page 4

II. Treaties and Protocols

Page 7

1. Convention relating to the Status of Refugees (1951) and its Protocol (1967)

2. Vienna Convention on Consular Relations (1963)

3. International Convention on the Elimination of All Forms of Racial Discrimination (1965)

4. International Covenant on Civil and Political Rights (1966)

5. Convention on the Elimination of All Forms of Discrimination against Women (1979)

6. Convention against Torture (1984) and its Optional Protocol (2002)

7. Convention on the Rights of the Child (1989) and its Optional Protocol (2000)

8. International Convention on the Protection of the Rights of All Migrant Workers and Members of their Families (1990)

9. Protocol to Prevent, Suppress, and Punish Trafficking in Persons, Especially Women and Children, supplementing the United Nations Convention against Transnational Organized Crime (2000)

10. Protocol against the Smuggling of Migrants by Land, Sea, and Air , supplementing the United Nations Convention against Transnational Organized Crime (2000)

\section{UN Declarations, Principles, and Guidelines}

1. Standard Minimum Rules for the Treatment of Prisoners (1977)

2. Declaration on the Human Rights of Individuals Who Are not Nationals of the Country in which They Live (1985)

3. Body of Principles for the Protection of All Person under Any Form of Detention or Imprisonment (1988)

4. Rules for the Protection of Juveniles Deprived of their Liberty (1990)

\section{UN Charter-Based Mechanisms}

1. Special Rapporteur on Torture and Other Cruel, Inhuman or Degrading Treatment or Punishment

\footnotetext{
* Isabel Ricupero is a legal consultant to the Global Detention Project (GDP) and the former assistant to the UN Special Rapporteur on the Human Rights of Migrants. Michael Flynn is the GDP's founder and lead researcher. The GDP is based at the Program for the Study of Global Migration of the Graduate Institute of International and Development Studies in Geneva, Switzerland. The authors would like to thank Mariette Grange and Vincent Chetail for their comments on an earlier draft of this paper. Any errors in the paper are those of the authors. Research for this paper was made possible by the generous support of the Graduate Institute and the Geneva International Academic Network.
} 
2. Working Group on Arbitrary Detention

3. Special Rapporteur on the Human Rights of Migrants

4. Special Rapporteur on the Trafficking in Persons

5. Special Rapporteur on Violence against Women

6. Special Rapporteur on the Sale of Children, Child Prostitution, and Child Pornography

1. Europe

- Council of Europe

- European Union

- European Convention on Human Rights

- European Court of Human Rights

- Relevant Rulings of the European Court of Human Rights

- European Convention for the Prevention of Torture

- Council of Europe Convention against Trafficking

- Relevant European Union Directives

2. The Americas

- American Declaration on the Rights and Duties of Man

- American Convention on Human Rights

- Inter-American Commission on Human Rights

- Relevant Decisions of the Inter-American Commission

- Inter-American Court of Human Rights

- Cartagena Declaration on Refugees

3. Other Regional Systems

- African Union

- League of Arab States

VI. Additional Sources

Page 39

1. Conventions of the International Labor Organization

2. International Humanitarian Law

VII. References

Page 44

1. Alphabetical Listing

2. Official Documents 


\section{Introduction}

In September 2009, during a special session of the UN Human Rights Council devoted to the detention of immigrants and asylum seekers, the UN High Commissioner for Human Rights Navi Pillay remarked that the plight of "migrants, and particularly migrants in an irregular situation, is one of today's most critical human rights challenges.” Pillay highlighted a number of concerns, including the growing criminalization of irregular migration, the need to combat arbitrary detention, and the often deplorable conditions in which migrants are detained. She stated that "international human rights norms and standards provide us with a solid legal framework to address the critical challenges related to the detention of irregular migrants” and urged the Human Rights Council to help ensure that the treatment of detained migrants complies with these standards.

This Global Detention Project (GDP) working paper attempts to map the web of international and regional instruments and mechanisms that together make up the "solid legal framework" relevant to the phenomenon of migration-related detention, which the Global Detention Project defines as the "deprivation of liberty of non-citizens because of their status." Deprivation of liberty on these grounds typically takes the form of administrative detentiondetention in the absence of a criminal charge-though there are increasing instances of states criminalizing irregular entry or presence. Migrant detainees can include asylum seekers and refugees, irregular immigrants, stateless persons, and victims of trafficking.

To be sure, there have been other efforts by academics and human rights experts to address the international legal framework for the administrative detention of migrants. Many of these have aimed at developing legal arguments by viewing the content of treaties through the lens of specific norms. ${ }^{1}$ In contrast to these efforts, the modest intent of this working paper is to individually identify each relevant legal instrument and body, briefly describing their significance to the phenomenon of immigration-related detention.

This effort serves a number of purposes: First, it demonstrates the broad expanse of international instruments, above and beyond the core human rights conventions, that have provisions applicable to the rights of detained migrants. Second, it provides readers with a ready-made handbook for identifying how specific legal instruments and human rights bodies can have relevance to detention situations. Lastly, this legal mapping endeavor serves as a preliminary stage in the effort by the Global Detention Project to build a database aimed at measuring state compliance with international obligations.

The working paper is organized according to five main sections: "Treaties and Protocols"; "UN Declarations, Principles, and Guidelines"; "UN Charter-Based Mechanisms"; "Regional Norms and Standards"; and "Additional Sources” (international humanitarian law and relevant conventions of the International Labor Organization).

Treaties and Protocols. There are a number of international instruments that contain provisions related to the rights of detainees that are particularly relevant to the detention of non-citizens. Provisions contained in treaties are binding on states parties. Customary law,

\footnotetext{
${ }^{1}$ See, for instance, Amnesty International, Migration-Related Detention: A Research Guide on Human Rights Standards relevant to the Detention of Migrants, Asylum Seekers and Refugees, November 2007; and Andi Pacurar, "Smuggling, Detention, and Expulsion of Irregular Migrants: A Study on International Legal Norms, Standards, and Practices,” European Journal of Migration and Law, 2003.
} 
which generally reflects the practice and views of states in the international system regarding their international obligations, is also binding on states under international law.

Treaties with universal vocation - those open to ratification by all states-that can be relevant to migration-related detention include: the Convention relating to the Status of Refugees and its 1967 Protocol; the Vienna Convention on Consular Relations; the International Convention on the Elimination of All Forms of Racial Discrimination; the International Covenant on Civil and Political Rights; the Convention on the Elimination of All Forms of Discrimination against Women; the Convention against Torture and Other Cruel, Inhuman, or Degrading Treatment or Punishment and its Optional Protocol; the Convention on the Rights of the Child and its Optional Protocol on the Sale of Children, Child Prostitution, and Child Pornography; the International Convention on the Protection of the Rights of All Migrant Workers and Members of Their Families; and the two supplementary protocols to the UN Convention against Transnational Organized Crime- -the Protocol to Prevent, Suppress, and Punish Trafficking in Persons, Especially Women and Children; and the Protocol against the Smuggling of Migrants by Land, Sea, and Air. ${ }^{2}$

This section also describes the work of some of the bodies or organs that are charged with monitoring the implementation of treaties. These organs can clarify the content of international obligations, which are often formulated in a general manner, by expressing concern and making recommendations to governments (or, in the case of regional courts, by adopting binding decisions). Within the United Nations, among the treaty bodies relevant to migration-related detention are the Human Rights Committee, which monitors the implementation of the International Covenant on Civil and Political Rights; and the Committee on the Protection of the Rights of All Migrant Workers and Members of their Families, which was created by the International Convention on the Protection of the Rights of All Migrant Workers and Members of Their Families.

UN Declarations, Principles, and Guidelines. Some human rights instruments that are not formally binding in the same manner as treaties_-such as UN declarations and guidelinesnevertheless contain authoritative interpretations of states' obligations under international law. The most widely recognized instrument of this kind is the Universal Declaration of Human Rights (1948). Article 3 of the declaration affirms that "everyone has the right to life, liberty, and security of person."

These instruments can be particularly important in the context of countries that have failed to ratify the main human rights treaties because they are often evidence of a broad consensus in the international community, in particular when they are negotiated by UN member states and adopted by the UN General Assembly, and can reflect customary law.

At the UN level and in the context of the administrative detention of non-citizens, nonbinding instruments with particular relevance include: the Standard Minimum Rules for the Treatment of Prisoners; the Body of Principles for the Protection of All Persons under Any Form of Detention or Imprisonment; the Declaration on the Human Rights of Individuals

\footnotetext{
${ }^{2}$ There are additional human rights treaties that have relevance to categories of people who can be subject to administrative detention as a result of their status, in particular the two core treaties of the international statelessness regime: the 1954 Convention Relating to the Status of Stateless Persons and the 1961 Convention on the Reduction of Statelessness. However, both of these treaties suffer from poor ratification and provide limited protection. For a detailed discussion of the international legal framework on the detention of stateless persons, see Equal Rights Trust, The Protection of Stateless Persons in Detention under International Law, January 2009.
} 
Who Are not Nationals of the Country in which They Live; and the Rules for the Protection of Juveniles Deprived of their Liberty.

UN Charter-Based Mechanisms. The UN Human Rights Council has a number of independent enquiry mechanisms (known as "Special Procedures") that can generally receive complaints, carry out visits to countries, and undertake general studies on themes relevant to their mandates. These mandates address all countries in the world, applying relevant international norms and standards. When addressing specific countries these mandates take into account treaties ratified by the states. Two mandates that have particular relevance to the detention of non-nationals are the Special Rapporteur on the Human Rights of Migrants and the Working Group on Arbitrary Detention. Other relevant mechanisms include the Special Rapporteur on Torture; the Special Rapporteur on the Trafficking in Persons; the Special Rapporteur on Violence against Women; and the Special Rapporteur on the Sale of Children, Child Prostitution, and Child Pornography.

Regional Norms and Standards. Countries can also be bound to treaties, decisions, or norms adopted by regional bodies or organs. Regional organizations-most notably the Council of Europe, the Organization of American States (OAS), and the African Union (AU) (successor to the Organization of African Unity) - have developed human rights norms and mechanisms that, generally, can be applicable to member states of these organizations. Regional-level implementing bodies include the European Court of Human Rights, the InterAmerican Commission on Human Rights, the Inter-American Court of Human Rights, the African Commission on Human and Peoples' Rights, and the African Court on Human and Peoples’ Rights.

Actions taken in the context of regional entities that are not directly aimed at human rights protection can also have an impact on the situation of non-citizens in detention. The clearest example is that of the European Union (EU), which has adopted or proposed directives with the objective of establishing common rules for all EU states, including standards for the reception of asylum seekers and a directive on returning "illegally-staying third-country nationals."

Additional Sources. In addition to the main international and regional human rights instruments and bodies are several legal regimes that can have relevance-albeit in some cases only indirectly — to the rights of migrant detainees. These include international labor standards that are enumerated in the various conventions and recommendations of International Labor Organization and protections afforded administrative detainees and refugees in international humanitarian law. 


\section{Treaties and Protocols}

1. Convention relating to the Status of Refugees (1951) and the Protocol relating to the Status of Refugees (1967)

2. Vienna Convention on Consular Relations (1963)

3. International Convention on the Elimination of All Forms of Racial Discrimination (1965)

4. International Covenant on Civil and Political Rights (1966)

5. Convention on the Elimination of All Forms of Discrimination against Women (1979)

6. Convention against Torture and Other Cruel, Inhuman, or Degrading Treatment or Punishment (1984) and the Optional Protocol to the Convention against Torture and Other Cruel, Inhuman, or Degrading Treatment or Punishment (2002)

7. Convention on the Rights of the Child (1989) and the Optional Protocol to the Convention on the Rights on the Sale of Children, Child Prostitution, and Child Pornography (2000)

8. International Convention on the Protection of the Rights of All Migrant Workers and Members of Their Families (1990)

9. Protocol to Prevent, Suppress, and Punish Trafficking in Persons, Especially Women and Children, supplementing the United Nations Convention against Transnational Organized Crime (2000)

10. Protocol against the Smuggling of Migrants by Land, Sea, and Air , supplementing the United Nations Convention against Transnational Organized Crime (2000)

\section{Convention Relating to the Status of Refugees (1951) and the Protocol Relating to the Status of Refugees (1967)}

The Convention Relating to the Status of Refugees, also referred to as the Refugee Convention, was adopted in the wake of World War II initially to aid the repatriation and resettlement of people displaced by the war. The convention consolidates previous norms relating to refugees, contains a definition of who refugees are, and describes the basic obligations of states regarding the treatment of refugees. It defines a refugee as a person who "owing to a well-founded fear of being persecuted for reasons of race, religion, nationality, membership of a particular social group, or political opinion, is outside the country of his nationality, and is unable to or, owing to such fear, is unwilling to avail himself of the protection of that country.”

The Protocol relating to the Status of Refugees removed restrictions present in the Refugee Convention at the moment of drafting, eliminating from the definition of refugee the condition that such persons must have suffered persecution as a result of "events occurring before 1 January 1951” and removing the convention's geographic limitations.

A key obligation of states, as spelled out in the Refugee Treaty, is the principle of nonrefoulement, which prohibits the expulsion or return of refugees to territories where their lives or freedom would be threatened because of their race, religion, nationality, membership in a particular social group, or political opinion. The UN High Commissioner for Refugees (UNHCR) has affirmed that the principle of non-refoulement constitutes a norm of customary international law and is thus obligatory for all states (UNHCR 1994).

Article 31 of the Refugee Convention establishes that no penalties will be imposed "on account of their illegal entry or presence, on refugees who, coming directly from a territory 
where their life or freedom was threatened ... enter or are present in their territory without authorization, provided they present themselves without delay to the authorities and show good cause for their illegal entry or presence."

Article 31 also states that restrictions on the movement of refugees shall be limited to only those that "are necessary," and that "such restrictions shall only be applied until their status in the country is regularized or they obtain admission into another country."

In February 1999, UNHCR published the "Revised Guidelines on Applicable Criteria and Standards relating to the Detention of Asylum Seekers," which reaffirmed an earlier conclusion of UNHCR's Executive Committee that the detention of asylum seekers should be an exceptional measure.

According to the Revised Guidelines, "Consistent with this Article [31], detention should only be resorted to in cases of necessity. The detention of asylum-seekers who come 'directly' in an irregular manner should, therefore, not be automatic, or unduly prolonged."

The “exceptional grounds” for detaining an asylum seeker, according to Guideline 3, are limited to the following: 1) to verify a person's identity; 2) to determine the elements on which the claim for refugee status or asylum are based; 3) when asylum-seekers have destroyed their travel and/or identity documents or have used fraudulent documents in order to mislead the authorities of the state in which they intend to claim asylum; 4) to protect national security or public order.

Additionally, the Revised Guidelines outline procedural safeguards for detention, including the right to legal counsel and where possible free legal assistance, the right to have the detention decision subjected to automatic independent review, and the right to challenge the necessity of the detention (Guideline 5). The guidelines also address the detention of persons under the age of 18; the detention of vulnerable persons, women, and stateless persons; and conditions of detention.

\section{Vienna Convention on Consular Relations (1963)}

The Vienna Convention on Consular Relations largely codified existing norms and practices of states regarding consular relations, in particular outlining legal rights and duties of states concerning the establishment and conduct of consular relations and the privileges and immunities enjoyed by consular officers and offices.

According to the Vienna Convention, arresting authorities have an obligation to advise the person arrested or detained in any manner of his or her rights of access to a consular representative and, if specifically requested by the detainee, to make arrangements for such access (Art. 36.1 (b)).

The Vienna Convention also determines that "consular officers shall have the right to visit a national of the sending State who is in prison, custody or detention, to converse and correspond with him and to arrange for his legal representation” (Art. 36.1(c)). 


\section{International Convention on the Elimination of All Forms of Racial Discrimination}

(1965)

The International Convention on the Elimination of All Forms of Racial Discrimination (ICERD) defines racial discrimination as "any distinction, exclusion, restriction, or preference based on race, colour, descent, or national or ethnic origin which has the purpose or effect of nullifying or impairing the recognition, enjoyment or exercise, on an equal footing, of human rights and fundamental freedoms in the political, economic, social, cultural or any other field of public life” (ICERD 1965)

The ICERD contains the obligation that states parties prohibit and eliminate racial discrimination in the enjoyment of civil, political, economic, social, and cultural rights (Art. 5). It also stipulates, among other rights, the right to security of person and protection by the state against violence or bodily harm (Art. 5(b)); and the obligation to provide protection and remedies, through the courts and other state institutions, against any acts of racial discrimination (Art. 6). Article 6 also stipulates the right to seek from such tribunals reparation or satisfaction for any damage suffered as a result of discrimination.

In its General Comment on discrimination against non-citizens, the Committee on the Elimination of Racial Discrimination (CERD) declared that states should "Ensure the security of non-citizens, in particular with regard to arbitrary detention, as well as ensure that conditions in centres for refugees and asylum-seekers meet international standards”(CERD 2004, para. 19).

Moreover, CERD has, in its examination of reports by states parties on the implementation of their obligations under the convention, addressed a number of issues relevant to non-citizens in detention, including trafficking and the detention of non-citizens (see, for example, CERD's concluding observations on South Africa regarding allegations of ill-treatment of undocumented migrants in detention (CERD 2006, para. 23)).

\section{International Covenant on Civil and Political Rights (1966)}

The International Covenant on Civil and Political Rights (ICCPR) details and expands some of the general rights enumerated in the Universal Declaration of Human Rights (1948).

Among the most important aspects of the covenant as it relates to the detention of noncitizens is its Article 9, which establishes that "Everyone has the right to liberty and security of person. No one shall be subjected to arbitrary arrest or detention. No one shall be deprived of his liberty except on such grounds and in accordance with such procedure as are established in law" (Art. 9.1). The same article stipulates that "Anyone who is deprived of his liberty by arrest or detention shall be entitled to take proceedings before a court, in order that the court may decide without delay on the lawfulness of his detention and order his release if the detention is not lawful” (Art. 9.4).

In its General Comment No. 8, the Human Rights Committee affirmed that the provisions of Article 9 that do not exclusively address persons involved in criminal procedures, and in particular the right to a court review provided for in article 9.4, are applicable to all types of deprivations of liberty by arrest or detention, including in cases of immigration control (Human Rights Committee 1982, para. 1). 
With regard to Article 9.1, the Human Rights Committee has found that "there is no basis for the ... claim that it is per se arbitrary to detain individuals requesting asylum" (A. v. Australia 1997, para. 9.3). On the other hand, the committee has considered, in the context of administrative detention, that any decisions to keep a person in detention should be open to "periodical review" so as to "reassess the necessity of detention" and that detention "should not continue beyond the period for which a State Party can provide appropriate justification" (Shafiq v Australia 2006, para. 7.2; A. v. Australia, 1997, para. 9.4; Bakhtiyari v. Australia 2003, para. 9.2).

The Human Rights Committee has specified that when considered together with illegal entry, certain factors - such as the risk of flight or lack of cooperation-may justify detention for a period of time but that "Without such factors detention may be considered arbitrary, even if entry was illegal” (A. v. Australia 1997, para. 9.4). Further, according to the committee, states should show that "there were no less invasive means of achieving the same ends" $(C \mathrm{v}$ Australia 2002, para. 8.2; Shams and others v Australia 2007, para. 7.2).

According to the Human Rights Committee, "court review of the lawfulness of detention ... which must include the possibility of ordering release, is not limited to mere compliance of the detention with domestic law. While domestic legal systems may institute differing methods for ensuring court review of administrative detention, what is decisive . . . is that such review is, in its effects, real and not merely formal. By stipulating that the court must have the power to order release 'if the detention is not lawful,' [the Covenant] . . . requires that the court be empowered to order release, if the detention is incompatible with the requirements in article 9, paragraph 1 , or in other provisions of the Covenant" (A. v. Australia 1997, para. 9.5; Shams and others v Australia 2007, para. 7.3).

Articles 10, 12, and 13 of the ICCPR are also relevant to administrative detention situations. Article 10 establishes that "All persons deprived of their liberty shall be treated with humanity and with respect for the inherent dignity of the human person.”

Article 12 protects freedom of movement. It provides: “1. Everyone lawfully within the territory of a State shall, within that territory, have the right to liberty of movement and freedom to choose his residence. 2. Everyone shall be free to leave any country, including his own." In one case, the Human Rights Committee found that a person was "lawfully in the territory" of a state party after an expulsion order had been issued as it had not been enforced (Celepli v. Sweden 1994, para. 9.2).

According to the Human Rights Committee, “As the scope of article 12, paragraph 2, is not restricted to persons lawfully within the territory of a State, an alien being legally expelled from the country is likewise entitled to elect the State of destination, subject to the agreement of that State” (Human Rights Committee 1999, para. 8).

Article 13 of the ICCPR determines that "An alien lawfully in the territory of a State Party to the present Covenant may be expelled there from only in pursuance of a decision reached in accordance with law and shall, except where compelling reasons of national security otherwise require, be allowed to submit the reasons against his expulsion and to have his case reviewed by, and be represented for the purpose before, the competent authority or a person or persons especially designated by the competent authority.”

In its examination of reports submitted by states parties regarding their implementation of obligations under the ICCPR, the Human Rights Committee has made a number of 
recommendations on issues relating to the detention of non-citizens in specific countries, including inter alia on the conditions of detention, the possibility of lodging complaints regarding allegations of ill-treatment, and the detention of asylum seekers and victims of trafficking. For an example of the committee's comments and recommendations on conditions and duration of detention of persons detained pending immigration procedures, Human Rights Committee 1998, para.19. For an example of the committee's recommendations on allegations of lack of adequate opportunity to apply for asylum and conditions of detention for non-citizens (in this case, on Italy's Lampedusa island), see Human Rights Committee 2006, para. 15.

\section{Convention on the Elimination of All Forms of Discrimination against Women (1979)}

Sometimes referred to as an "international bill of rights for women," the Convention on the Elimination of All Forms of Discrimination against Women (CEDAW) defines discrimination against women as "any distinction, exclusion, or restriction made on the basis of sex which has the effect or purpose of impairing or nullifying the recognition, enjoyment, or exercise by women, irrespective of their marital status, on a basis of equality of men and women, of human rights and fundamental freedoms in the political, economic, social, cultural, civil, or any other field.”

Article 6 of the CEDAW stipulates, "States Parties shall take all appropriate measures, including legislation, to suppress all forms of traffic in women and exploitation of prostitution of women.” In its 2006 recommendations to Malaysia, the Committee on the Elimination of Discrimination against Women stated that the country should "ensure that trafficked women and girls are not punished for violations of immigration laws and have adequate support to be in a position to provide testimony against their traffickers" (Committee on the Elimination of Discrimination against Women 2006, para 24).

\section{Convention against Torture and Other Cruel, Inhuman, or Degrading Treatment or Punishment (1984) and the Optional Protocol to the Convention against Torture (2002)}

According to Article 1 of the Convention against Torture (CAT), "the term 'torture' means any act by which severe pain or suffering, whether physical or mental, is intentionally inflicted on a person for such purposes as obtaining from him or a third person information or a confession, punishing him for an act he or a third person has committed or is suspected of having committed, or intimidating or coercing him or a third person, or for any reason based on discrimination of any kind, when such pain or suffering is inflicted by or at the instigation of or with the consent or acquiescence of a public official or other person acting in an official capacity.” Additionally, Article 16 establishes the obligation for all states parties to prevent the occurrence of "acts of cruel, inhuman, or degrading treatment or punishment which do not amount to torture as defined in Article 1, when such acts are committed by or at the instigation of or with the consent or acquiescence of a public official or other person acting in an official capacity.”

Regarding the rights of non-citizens, Article 3 establishes that "No State Party shall expel, return ('refouler'), or extradite a person to another State where there are substantial grounds for believing that he would be in danger of being subjected to torture." 
The convention also contains a number of provisions that address norms and practices in detention situations that can have relevance to non-citizens deprived of their liberty. Among these are Article 10, which establishes that "Each State Party shall ensure that education and information regarding the prohibition against torture are fully included in the training of law enforcement personnel, civil or military, medical personnel, public officials and other persons who may be involved in the custody, interrogation or treatment of any individual subjected to any form of arrest, detention or imprisonment"; and Article 11, which states that states parties "shall keep under systematic review interrogation rules, instructions, methods, and practices as well as arrangements for the custody and treatment of persons subjected to any form of arrest, detention, or imprisonment in any territory under its jurisdiction, with a view to preventing any cases of torture.”

In its examination of reports submitted by states parties on the implementation of their treaty obligations, the Committee against Torture has on a number of occasions made recommendations on issues linked to the detention of non-citizens. In its May 2007 concluding observations to Japan, the committee addressed non-refoulement, the detention of migrants, reciprocity rules for foreigners seeking to claim redress for issues linked to detention, and trafficking (Committee against Torture 2007a, paras. 14, 23, and 25). Also in May 2007, the Committee against Torture made recommendations on expulsion and the conditions of detention of asylum seekers in the Ukraine (Committee against Torture 2007b, para. 20). In its November 2006 observations of France, the committee addressed the summary procedures for consideration of asylum applications filed in detention centres or at borders and the lack of suspensive effect on deportation of certain appeals (Committee against Torture 2006, paras. 6 and 7).

The Optional Protocol to the Convention against Torture (OPCAT) seeks to prevent torture and ill-treatment through the establishment of a system of regular visits by independent international and national bodies to places of detention. At the international level, the OPCAT created the Sub-Committee on Prevention of Torture (OPCAT 2002, Art. 2). At the national level, states parties are obliged to create or designate "National Preventive Mechanisms," generally within one year of ratification of the OPCAT (OPCAT 2002, Art. 17). Visits by the sub-committee and national mechanisms are to be carried out regularly. All places of detention under the jurisdiction and control of states parties are subject to visits, including sites where non-citizens are held in administrative detention.

\section{Convention on the Rights of the Child (1989) and the Optional Protocol on the Sale of Children, Child Prostitution, and Child Pornography (2000)}

The Convention on the Rights of the Child (CRC) addresses several issues that can be relevant to the detention of non-citizen minors. It requires states parties to ensure that children are detained only as a measure of last resort and for the shortest possible period of time (CRC 1989, Art. 37(b)); and that "in all actions concerning children" states make the best interests of the child the primary consideration in their actions (CRC 1989, Art. 3).

Article 37(d) of the convention states that "Every child deprived of his or her liberty shall have the right to prompt access to legal and other appropriate assistance, as well as the right to challenge the legality of the deprivation of his or her liberty before a court or other competent, independent, and impartial authority, and to a prompt decision on any such action.” The CRC also establishes that every child deprived of liberty shall be treated with humanity and respect for the inherent dignity of the human person, and in a manner which 
takes into account the needs of persons of his or her age. In particular, every child deprived of liberty shall be separated from adults unless it is considered in the child's best interest not to do so and shall have the right to maintain contact with his or her family through correspondence and visits, save in exceptional circumstances (CRC 1989, Art. 37(c)). Additionally, the convention stipulates that measures be taken to ensure that "a child who is seeking refugee status or who is considered a refugee in accordance with applicable international or domestic law and procedures shall, whether unaccompanied or accompanied by his or her parents or by any other person, receive appropriate protection and humanitarian assistance in the enjoyment of applicable rights set forth in the present convention and in other international human rights or humanitarian instruments to which the said states are parties” (CRC 1989, Art 22.1).

In its General Comment No. 6, on the "Treatment of Unaccompanied and Separated Children outside Their Country of Origin," the Committee on the Rights of the Child elaborated on the principle that in cases of unaccompanied children, detention should always be a measure of last resort. According to the committee, "Where detention is exceptionally justified for other reasons, it shall be conducted in accordance with article 37 (b) of the Convention that requires detention to conform to the law of the relevant country and only to be used as a measure of last resort and for the shortest appropriate period of time. In consequence, all efforts, including acceleration of relevant processes, should be made to allow for the immediate release of unaccompanied or separated children from detention and their placement in other forms of appropriate accommodation" (Committee on the Rights of the Child 2005a, paras. 62). The committee did not specify which "forms of appropriate accommodation” for unaccompanied children it regarded as non-detention situations.

Also in its General Comment No. 6, the Committee on the Rights of the Child described the required conditions of detention and the rights of children placed in detention (Committee on the Rights of the Child 2005a, paras. 61-63).

The Committee on the Rights of the Child has, in its examination of reports submitted by states parties regarding implementation of their treaty obligations, made recommendations on the issue of the administrative detention of child non-citizens. In its 2005 recommendations to Australia , for example, the committee addressed the automatic detention of children irregularly in the country, legal safeguards made available to them, and the conditions of their detention (Committee on the Rights of the Child, Concluding Observations: Australia, 30 September 2005b, paras. 62-64).

The Optional Protocol to the Convention on the Rights of the Child (OPSC) contains provisions to ensure the criminalization, investigation, and prosecution of the sale of children, child prostitution, and child pornography. It also provides for the protection of child victims (OPSC 2000).

In its examination of reports on states parties' implementation of their obligations under the OPSC, the Committee on the Rights of the Child has made recommendations on the detention of non-citizen children. In its October 2007 Concluding Observations to France, for example, the committee expressed concern over how asylum seekers and unaccompanied children are treated when held in waiting zones of airports. It recommended that France implement a number of procedural safeguards and that it ensure that "children in need of international protection and who are at risk of being re-trafficked are not returned to the country where this danger exists” (Committee on the Rights of the Child 2007, paras. 6-7 \& 24-25). 


\section{International Convention on the Protection of the Rights of All Migrant Workers and Members of Their Families (1990)}

The International Convention on the Protection of the Rights of All Migrant Workers and Members of Their Families (ICRMW) states that "Migrant Workers and members of their families shall not be subjected individually or collectively to arbitrary arrest or detention; they shall not be deprived of their liberty except on such grounds and in accordance with such procedures as are established by law” (ICRMW 1990, Art.16.4).

The ICRMW provides that migrant workers and members of their families who are under any form of detention must be able to communicate with their consular authorities (ICRMW 1990, Art. 16.7) and "be entitled to take proceedings before a court, in order that that court may decide without delay on the lawfulness of their detention and order their release if the detention is not lawful. When they attend such proceedings, they shall have the assistance, if necessary without cost to them, of an interpreter, if they cannot understand or speak the language used” (ICRMW 1990, Art. 16.8).

The ICRMW also establishes that migrant workers and members of their families who are deprived of their liberty "shall be treated with humanity and with respect for the inherent dignity of the human person and for their cultural identity" (ICRMW 1990, Art. 17.1); that persons held "for violation of provisions relating to migration shall be held, in so far as practicable, separately from convicted persons or persons detained pending trial" (ICRMW 1990, Art. 17.3); and that "If a migrant worker or a member of his or her family is detained for the purpose of verifying any infraction of provisions related to migration, he or she shall not bear any costs arising therefrom” (ICRMW 1990, Art. 17.8).

The Committee on the Protection of the Rights of All Migrant Workers and Members of their Families (CMW), in its examination of reports by states parties on the implementation of their treaty obligations, has made recommendations on the situation of non-citizens held in administrative detention. For instance, the CMW's November 2006 recommendations to Mexico regarding, inter alia, conditions of detention of migrant holding centres, addressed the possibility of lodging complaints regarding ill-treatment and notification of consular authorities (Committee on Migrant Workers 2006, paras. 27-28). 


\section{Protocol to Prevent, Suppress, and Punish Trafficking in Persons, Especially Women and Children supplementing the United Nations Convention against Transnational Organized Crime (2000)}

The Trafficking in Persons Protocol, a protocol to the 2000 Convention against Transnational Organized Crime (also known as the Palermo Convention), has among its aims combating trafficking in persons, which the protocol defines as "the recruitment, transportation, transfer, harbouring, or receipt of persons, by means of the threat or use of force or other forms of coercion, of abduction, of fraud, of deception, of the abuse of power, or of a position of vulnerability, or of the giving or receiving of payments or benefits to achieve the consent of a person having control over another person, for the purpose of exploitation. Exploitation shall include, at a minimum, the exploitation of the prostitution of others or other forms of sexual exploitation, forced labour or services, slavery or practices similar to slavery, servitude or the removal of organs” (Trafficking in Persons Protocol 2000, Art. 3(a)).

The protocol provides that states parties "consider implementing measures to provide for the physical, psychological, and social recovery of victims of trafficking in persons ... in particular, the provision of: (a) Appropriate housing; (b) Counselling and information, in particular as regards their legal rights, in a language that the victims of trafficking in persons can understand; (c) Medical, psychological, and material assistance; and (d) Employment, educational, and training opportunities (Trafficking in Persons Protocol 2000, Art. 6.3).

The protocol also provides that states parties "consider adopting legislative or other appropriate measures that permit victims of trafficking in persons to remain in its territory, temporarily or permanently, in appropriate cases" (Trafficking in Persons Protocol 2000, Art. 7.1).

Complementing the protocol is the "Recommended Principles and Guidelines on Human Rights and Human Trafficking” (2002), which was compiled by the Office of the High Commissioner for Human Rights (OHCHR) to provide practical policy guidance for the protection of trafficked persons and the prevention of trafficking.

The Recommended Principles and Guidelines provide that states should consider "Ensuring that trafficked persons are not, in any circumstances, held in immigration detention or other forms of custody" (OHCHR 2002, Guideline 2, para. 6). They urge states to consider "Ensuring that the legislation prevents trafficked persons from being prosecuted, detained, or punished for the illegality of their entry or residence or for the activities they are involved in as a direct consequence of their situation as trafficked persons” (OHCHR 2002, Guideline 4, para. 5). They also provide that states (as well as intergovernmental organizations and nongovernmental organizations, when applicable) should consider "Ensuring, in cooperation with non-governmental organizations, that safe and adequate shelter that meets the needs of trafficked persons is made available" and that trafficked persons "not be held in immigration detention centres, other detention facilities, or vagrant houses” (OHCHR 2002, Guideline 6, para. 1). 


\section{Protocol against the Smuggling of Migrants by Land, Sea, and Air, supplementing the United Nations Convention against Transnational Organized Crime (2000)}

The Protocol against the Smuggling of Migrants, which supplements the 2000 Convention against Transnational Organized Crime, contains the obligation for states parties to criminalize smuggling and related acts (Protocol Against the Smuggling of Migrants 2002, Art. 6). It also provides that migrants shall not be liable to criminal prosecution under the protocol for having been the object of smuggling (Protocol Against the Smuggling of Migrants 2002, Art. 5).

Additionally, the protocol contains an obligation for states parties to facilitate the return of smuggled persons who are their nationals and to consider the possibility of facilitating the return of permanent residents, including - when necessary-by issuing travel documents or other necessary authorizations (Protocol Against the Smuggling of Migrants 2002, Art. 18). 


\section{UN Declarations, Principles, Guidelines}

1. Standard Minimum Rules for the Treatment of Prisoners (1977)

2. Declaration on the Human Rights of Individuals Who Are not Nationals of the Country in which They Live (1985)

3. Body of Principles for the Protection of All Person under Any Form of Detention or Imprisonment (1988)

4. $\quad$ Rules for the Protection of Juveniles Deprived of their Liberty (1990)

\section{The Standard Minimum Rules for the Treatment of Prisoners (1955)}

The "Standard Minimum Rules for the Treatment of Prisoners" were first adopted by the UN Congress on the Prevention of Crime and the Treatment of Offenders in 1955. They were later approved by the UN Economic and Social Council (ECOSOC) through resolutions adopted in 1957 and 1977. In 1971, the UN General Assembly Resolution 2858, entitled Human Rights in the Administration of Justice, recommended that member states implement the rules in the administration of penal and correctional institutions and consider incorporating them in national legislation.

The Standard Minimum Rules address a broad range of issues, observing that "In view of the great variety of legal, social, economic, and geographical conditions of the world, it is evident that not all of the rules are capable of application in all places and at all times. They should, however, serve to stimulate a constant endeavor to overcome practical difficulties in the way of their application, in the knowledge that they represent, as a whole, the minimum conditions which are accepted as suitable by the United Nations.”

Part I of the rules covers the general management of institutions. These rules are applicable to all categories of prisoners, criminal or civil, untried or convicted, including prisoners subject to "security measures" or corrective measures ordered by the judge.

Issues covered in Part I that can be relevant to migration-related detention include: registration; the separation of different categories of prisoners, including the "legal reason for their detention"; minimum standards for accommodation, clothing, bedding, food, exercise, and medical services; complaint mechanisms for prisoners; and contacts with the outside world.

Part II of the Standard Minimum Rules, which encompass rules that are applicable to special categories of detainees, determines that "In countries where the law permits imprisonment for debt, or by order of a court under any other non-criminal process, persons so imprisoned shall not be subjected to any greater restriction or severity than is necessary to ensure safe custody and good order." 


\section{Declaration on the Human Rights of Individuals Who Are not Nationals of the Country in which They Live (1985)}

Adopted by the UN General Assembly in 1985, the "Declaration on the Human Rights of Individuals Who Are Not Nationals of the Country in Which They Live" defines an "alien" as "any individual who is not a national of the state in which he or she is present" (Art. 1). It determines that aliens shall enjoy a broad range of civil, economic, social, and cultural rights; provides that no alien shall be subjected to arbitrary arrest or detention; and provides that no alien shall be deprived of his or her liberty except on such grounds and in accordance with such procedures as are established by law (Art. 5.1(a)). Additionally, the declaration provides that all aliens "shall be free at any time to communicate with the consulate or diplomatic mission of the State of which he or she is a national" (Art. 10).

Aliens "lawfully" in the territory of a state may be expelled only as a result of a decision reached in accordance with law and shall "be allowed to submit the reasons why he or she should not be expelled" and "to have the case reviewed by, and be represented for the purpose before,” a competent authority (Art. 7).

\section{The Body of Principles for the Protection of All Persons under Any Form of Detention or Imprisonment (1988)}

Adopted by the UN General Assembly on December 9, 1988, “The Body of Principles for the Protection of All Persons under Any Form of Detention or Imprisonment" contains detailed provisions for the protection of persons held in any type of detention.

Many of the principles are relevant to non-citizens held in administrative detention, including: Principle 4, which provides that any form of detention shall be ordered by, and be subject to, the effective control of a judicial or other authority; Principle 11, which determines that a person shall not be kept in detention without being given an effective opportunity to be heard promptly by a judicial or other authority and the right to be assisted by counsel; Principle 15, which affirms the right of detainees to not be denied communication with the outside world, in particular his family or counsel, for "more than a matter of days"; Principle 16, which provides that a non-citizen in detention shall be promptly informed of his right to communicate by appropriate means with a consular post or the diplomatic mission of the state of which he is a national (or, in the case of a refugee under the protection of an intergovernmental organization, with the representative of the competent international organization); and Principle 32, which affirms the right of detained persons to challenge the lawfulness of his or her detention. 
The "UN Rules for the Protection of Juveniles Deprived of their Liberty," adopted by the General Assembly in December 1990 (Resolution 45/113), elaborate on norms contained in the Convention on the Rights of the Child, in particular those regarding the deprivation of liberty of any person under the age of 18 . The rules establish the minimum standards accepted by the United Nations "for the protection of juveniles deprived of their liberty in all forms, consistent with human rights and fundamental freedoms, and with a view to counteracting the detrimental effects of all types of detention and to fostering integration in society.” Among the minimum standards addressed in the UN Rules are the rights and guarantees of juveniles in detention, the management of detention facilities, the conditions of the environment and accommodations at detention facilities, and the grounds upon which juveniles can be detained. Rule 2 establishes, "Deprivation of the liberty of a juvenile should be a disposition of last resort and for the minimum necessary period and should be limited to exceptional cases. The length of the sanction should be determined by the judicial authority, without precluding the possibility of his or her early release.”

The UN Rules also provide a definition for “deprivation of liberty.” According to Rule 11, "The deprivation of liberty means any form of detention or imprisonment or the placement of a person in a public or private custodial setting, from which this person is not permitted to leave at will, by order of any judicial, administrative or other public authority.” 


\section{UN Charter-Based Human Rights Mechanisms}

1. Special Rapporteur on Torture and Other Cruel, Inhuman or Degrading Treatment or Punishment

2. Working Group on Arbitrary Detention

3. Special Rapporteur on the Human Rights of Migrants

4. $\quad$ Special Rapporteur on the Trafficking in Persons

5. Special Rapporteur on Violence against Women

6. Special Rapporteur on the Sale of Children, Child Prostitution, and Child Pornography

\section{Special Rapporteur on Torture and Other Cruel, Inhuman, or Degrading Treatment or Punishment}

The mandate of the Special Rapporteur on Torture, which was created in 1985 by Commission Resolution 1985/33 to examine questions relevant to torture, investigates a broad range of issues related to detention situations. Among its activities, the Special Rapporteur transmits urgent appeals with regards to individuals at risk and communications about alleged cases of torture and ill treatment, and undertakes fact-finding country visits.

The Special Rapporteur has occasionally addressed the treatment of non-citizens in detention. For example, in a 2003 report to the Commission on Human Rights, the Special Rapporteur highlighted migration-related detention as a factor that can conduce to ill treatment: "The Special Rapporteur notes that one of the most frequent obstacles to the respect of the human dignity and to the prohibition of torture and other forms of ill-treatment in places of detention is overcrowding. In order to improve the conditions of detention and in accordance with international standards ... the Special Rapporteur encourages States to avoid holding people in custody where possible. This is particularly applicable in cases of pre-trial detention and detention of children, asylum-seekers, and refugees” (Special Rapporteur on Torture 2003, para. 49).

In addition, the Special Rapporteur has highlighted the precarious legal situation of those in administrative detention, and called on states to consider abolishing the practice.

"Administrative detention often puts detainees beyond judicial control. Persons under administrative detention should be entitled to the same degree of protection as persons under criminal detention. At the same time, countries should consider abolishing, in accordance with relevant international standards, all forms of administrative detention” (Special Rapporteur on Torture 2001, para. 39).

Lastly, the Special Rapporteur has stated that regular visits and inspections at places of detention are key to preventing abuses, emphasizing that independent nongovernmental organizations in addition to official bodies should be given access to all detention facilities, including those used to hold people in administrative detention. "Independent nongovernmental organizations should be authorized to have full access to all places of detention, including police lock-ups, pre-trial detention centres, security service premises, administrative detention areas and prisons, with a view to monitoring the treatment of persons and their conditions of detention. When inspection occurs, members of the inspection team should be afforded an opportunity to speak privately with detainees. The team should also 
report publicly on its findings. In addition, official bodies should be set up to carry out inspections, such teams being composed of members of the judiciary, law enforcement officials, defence lawyers and physicians, as well as independent experts and other representatives of civil society. Ombudsmen and national or human rights institutions should be granted access to all places of detention with a view to monitoring the conditions of detention. When it so requests, the International Committee of the Red Cross should be granted access to places of detention ” (Special Rapporteur on Torture 2001, para. 39).

\section{Working Group on Arbitrary Detention}

The Working Group on Arbitrary Detention (WGAD), set up by the Human Rights Commission in 1991 by Resolution 1991/42, was created "To investigate cases of deprivation of liberty imposed arbitrarily, provided that no final decision has been taken in such cases by domestic courts in conformity with domestic law, with the relevant international standards set forth in the Universal Declaration of Human Rights and with the relevant international instruments accepted by the States concerned" (WGAD 2008).

In 1997, the Working Group’s mandate was expanded by resolution 1997/50 of the Commission on Human Rights to include a specific focus on the detention of immigrants and asylum seekers. This resolution requested that the Working Group "devote all necessary attention to reports concerning the situation of immigrants and asylum seekers who are allegedly being held in prolonged administrative custody without the possibility of administrative or judicial remedy.”

The Working Group acts on information of alleged cases of arbitrary detention by sending urgent appeals and other communications to the governments concerned. The Working Group is the only non-treaty-based mechanism that can investigate and issue an opinion on individual cases (WGAD 2008).

The Working Group has on several occasions addressed the question of the detention of noncitizens. In its 1999 report to the Commission on Human Rights, the Working Group enumerated 14 "guarantees" that provide criteria for determining whether the detention of a non-citizen is arbitrary (WGAD 1998, paras. 69-70). In its 2000 report to the commission, the Working Group indicated 10 "principles" on the detention of asylum seekers and immigrants (WGAD 1999). And in its 2008 report to the Human Rights Council, the Working Group reiterated its concern with the administrative detention of non-citizens (WGAD 2008, paras. 41-54).

The 10 principles enumerated in the Working Group’s 2000 report to the commission:

Principle 1: Any asylum-seeker or immigrant, when held for questioning at the border, or inside national territory in the case of illegal entry, must be informed at least orally, and in a language which he or she understands, of the nature of and grounds for the decision refusing entry at the border, or permission for temporary residence in the territory, that is being contemplated with respect to the person concerned.

Principle 2: Any asylum-seeker or immigrant must have the possibility, while in custody, of communicating with the outside world, including by telephone, fax or electronic mail, and of contacting a lawyer, a consular representative and relatives. 
Principle 3: Any asylum-seeker or immigrant placed in custody must be brought promptly before a judicial or other authority.

Principle 4: Any asylum-seeker or immigrant, when placed in custody, must enter his or her signature in a register which is numbered and bound, or affords equivalent guarantees, indicating the person's identity, the grounds for the custody and the competent authority which decided on the measure, as well as the time and date of admission into and release from custody.

Principle 5: Any asylum-seeker or immigrant, upon admission to a centre for custody, must be informed of the internal regulations and, where appropriate, of the applicable disciplinary rules and any possibility of his or her being held incommunicado, as well as of the guarantees accompanying such a measure.

Principle 6: The decision must be taken by a duly empowered authority with a sufficient level of responsibility and must be founded on criteria of legality established by the law.

Principle 7: A maximum period should be set by law and the custody may in no case be unlimited or of excessive length.

Principle 8: Notification of the custodial measure must be given in writing, in a language understood by the asylum-seeker or immigrant, stating the grounds for the measure; it shall set out the conditions under which the asylum-seeker or immigrant must be able to apply for a remedy to a judicial authority, which shall decide promptly on the lawfulness of the measure and, where appropriate, order the release of the person concerned.

Principle 9: Custody must be effected in a public establishment specifically intended for this purpose; when, for practical reasons, this is not the case, the asylum-seeker or immigrant must be placed in premises separate from those for persons imprisoned under criminal law.

Principle 10: The Office of the United Nations High Commissioner for Refugees (UNHCR), the International Committee of the Red Cross (ICRC) and, where appropriate, duly authorized non-governmental organizations must be allowed access to the places of custody.

\section{Special Rapporteur on the Human Rights of Migrants}

The mandate of the Special Rapporteur on the Human Rights of Migrants was created in 1999 by the Commission on Human Rights to "examine ways and means to overcome the obstacles existing to the full and effective protection of the human rights of migrants, including obstacles and difficulties for the return of migrants who are undocumented or in an irregular situation” (Human Rights of Migrants 1999, Resolution 1999/44).

The Special Rapporteur has on several occasions addressed the question of the administrative detention of migrants, including in a 2003 thematic study by then-Special Rapporteur Gabriela Rodríguez Pizarro (Special Rapporteur on the Human Rights of Migrants 2002) and in a 2008 report by Special Rapporteur Jorge Bustamante (Special Rapporteur on the Human Rights of Migrants 2008). The Special Rapporteur has also addressed migration-related detention in a number of its communications to governments and in reports on country visits (see for example reports on visits to Italy 2004, and the United States of America 2008b). 
In her 2003 report, the Special Rapporteur made a number of specific recommendations regarding the detention of migrants, including: that infractions of immigration laws and regulations should not be considered criminal offences under national legislation; that governments consider the possibility of progressively abolishing all forms of administrative detention; that legislation not allow for the detention of unaccompanied children and that persons only be detained on the basis of criteria established by law; that administrative detainees be entitled to bring proceedings before a court, be assisted by legal counsel, and an interpreter free of charge (Special Rapporteur on the Human Rights of Migrants Gabriela Rodriguez 2002, paras. 72-75).

In his February 2008 report to the Human Right Council, the Special Rapporteur addressed the issue of detention in international transit zones: "Migrants and asylum-seekers are sometimes detained at airport transit zones and other points of entry, under no clear authority, either with the knowledge of government officials at the airport or simply on the instructions of airline companies before being returned to their countries. The difficulty or impossibility of reaching any outside assistance impedes the exercise of the right of the persons concerned to challenge the lawfulness of the State's decision to be detained and returned and to apply for asylum, even in the presence of legitimate claims" (Special Rapporteur on the Human Rights of Migrants Jorge Bustamante 2008a, para. 47).

\section{Special Rapporteur on the Trafficking in Persons, Especially Women and Children}

The Special Rapporteur on Trafficking was created by the Commission on Human Rights in its Resolution 2004/110 to act on the human rights aspects of the victims of trafficking in persons. The Special Rapporteur has addressed the question of the detention of victims of trafficking (see, for example, the Special Rapporteur Sigma Huda's report on her visit to Lebanon 2006, paras. 92-94).

The Special Rapporteur's mandate makes particular reference to the "Recommended Principles and Guidelines on Human Rights and Human Trafficking” which was developed by the Office of the High Commissioner for Human Rights (2002) within the broader framework of the Protocol to Prevent, Suppress, and Punish Trafficking in Persons, Especially Women and Children (2000), Supplementing the UN Convention against Transnational Organized Crime (2000).

The Recommended Principles and Guidelines provide that states should consider "Ensuring that trafficked persons are not, in any circumstances, held in immigration detention or other forms of custody" (2002, Guideline 2, para. 6). They urge States to consider "Ensuring that the legislation prevents trafficked persons from being prosecuted, detained, or punished for the illegality of their entry or residence or for the activities they are involved in as a direct consequence of their situation as trafficked persons” (2002, Guideline 4, para. 5). They also provide that states (as well as intergovernmental organizations and non-governmental organizations, when applicable) should consider "Ensuring, in cooperation with nongovernmental organizations, that safe and adequate shelter that meets the needs of trafficked persons is made available" and that trafficked persons "not be held in immigration detention centres, other detention facilities, or vagrant houses” (2002, Guideline 6, para. 1). 


\section{Special Rapporteur on Violence against Women, its Causes and Consequences}

The mandate of the Special Rapporteur on Violence against Women was created by the Commission on Human Rights through resolution 1994/45, adopted in 1994. The mandate has addressed the detention and protection of migrant and trafficked women on a number of occasions. The issue was examined in 2000 by the then-Special Rapporteur Ms. Radhika Coomaraswamy in her report on trafficking in women, women's migration, and violence against women (Special Rapporteur on Violence against Women, its Causes and Consequences Radhika Coomaraswamy 2000). In her report on her 2006 visit to the Netherlands, the rapporteur recommended that the government adopt measures to ensure that undocumented migrant women have access to women's shelters (Special Rapporteur on Violence against Women Yakin Ertürk 2007, para. 92(d)).

\section{Special Rapporteur on the Sale of Children, Child Prostitution, and Child Pornography}

The Special Rapporteur on the Sale of Children, Child Prostitution, and Child Pornography was created in 1990 by the Commission on Human Rights in its Resolution 1990/68. Its mandate is to "investigate the exploitation of children around the world and to submit reports thereon to the General Assembly and the Commission on Human Rights, making recommendations for the protection of the rights of the children concerned" (Special Rapporteur on the Sale of Children, Child Prostitution and Child Pornography website 2008).

The rapporteur, which during country visits often visits centres where children are placed or confined, has taken up the issue of detained migrant or non-citizen children, in particular unaccompanied children and victims of trafficking (see the Special Rapporteur Juan Miguel Petit's 2008 report on Mexico and 2003 report on France). Additionally, the mandate has sent communications to governments, often jointly with the mandates on trafficking and/or the human rights of migrants, concerning the situation of foreign children confined in immigration detention or other holding centres. 


\section{Regional Norms and Standards}

1. Europe

2. The Americas

3. Other Regional Systems

\section{Europe}

- $\quad$ Council of Europe

- $\quad$ European Union

- $\quad$ European Convention on Human Rights

- $\quad$ European Court of Human Rights

- $\quad$ Relevant Rulings of the European Court of Human Rights

- $\quad$ European Convention for the Prevention of Torture

- $\quad$ Council of Europe Convention against Trafficking

- $\quad$ Relevant European Union Directives

\section{Council of Europe}

The Council of Europe was founded in 1949 and comprises 47 member states (as of 2009). The Council places particular emphasis on legal standards and the protection of human rights, democratic development, and the rule of law. At the heart of the council is the Convention for the Protection of Human Rights and Fundamental Freedoms, adopted in 1950, which is more commonly known as the European Convention on Human Rights (ECHR). The convention created the European Court of Human Rights, which can receive complaints from individuals alleging violations of their rights under the convention and its protocols.

Also under the auspices of the Council of Europe is the European Convention for the Prevention of Torture and Inhuman or Degrading Treatment or Punishment, adopted in 1987, which created the European Committee for the Prevention of Torture and Inhuman or Degrading Treatment or Punishment (CPT). The CPT is competent to carry out regular visits to places of detention in the territories within the jurisdiction of states parties. The CPT's reports on country visits - as well as states' responses to theses reports-are a particularly rich resource for those wishing to investigate state practices vis-à-vis all types of detention, including migration-related detention (see CPT website, "States: Documents and Visits”).

Member states of the Council of Europe as of October 2009 included: Albania, Andorra, Armenia, Austria, Azerbaijan, Belgium, Bosnia and Herzegovina, Bulgaria, Croatia, Cyprus, Czech Republic, Denmark, Estonia, Finland, France, Georgia, Germany, Greece, Hungary, Iceland, Ireland, Italy, Latvia, Liechtenstein, Lithuania, Luxembourg, Malta, Moldova, Monaco, Montenegro, Netherlands, Norway, Poland, Portugal, Romania, Russian Federation, San Marino, Serbia, Slovakia, Slovenia, Spain, Sweden, Switzerland, "The former Yugoslav Republic of Macedonia," Turkey, Ukraine, and the United Kingdom. 


\section{European Union}

Action taken within the context of the European Union (EU) can be relevant to the situation of non-citizens in detention. The EU is the union of 27 states (as of 2009) to develop political, economic, and social cooperation. Important institutions and bodies of the EU include the European Commission, the European Parliament, the Council of the European Union, the European Court of Justice, and the European Central Bank.

The EU has endeavored to adopt common policies for all member states in a number of areas, including immigration, which falls under the European Commission's Directorate General for Justice, Freedom, and Security. This has lead to the adoption of directives that are relevant to the situation of non-citizens in detention, such as standards for the reception of asylum seekers. (For more on common policies, see the subheading below, "Relevant European Union Directives.")

Member states of the EU are also members of the Council of Europe and thus bound by the various human rights norms and standards that exist within that framework. EU members as of October 2009 included: Austria, Belgium, Bulgaria, Cyprus, Czech Republic, Denmark, Estonia, Finland, France, Germany, Greece, Hungary, Ireland, Italy, Latvia, Lithuania, Luxembourg, Malta, Netherlands, Poland, Portugal, Romania, Slovakia, Slovenia, Spain, Sweden, and the United Kingdom.

\section{European Convention on Human Rights (1950)}

The Convention for the Protection of Human Rights and Fundamental Freedoms, also known as the European Convention on Human Rights, was adopted in 1950 and entered into force in 1953. The convention has been supplemented by several additional protocols, which have extended the number of protected rights and freedoms and reformed the functioning of the protection system created by the treaty.

The European Convention protects the rights to liberty and security of the person under article 5, which establishes that "Everyone has the right to liberty and security of person" and that "No one shall be deprived of his liberty" except under certain circumstances and "in accordance with a procedure prescribed by law." The European Convention is the only one of the general human rights treaties to specifically enumerate the grounds that can lawfully justify a deprivation of liberty. Among those circumstances are "the lawful arrest or detention of a person to prevent his effecting an unauthorized entry into the country or of a person against whom action is being taken with a view to deportation or extradition"(Art. 5, Para. $1(\mathrm{f}))$.

Article 5 Paragraph 4 of the European Convention determines that "Everyone who is deprived of his liberty by arrest or detention shall be entitled to take proceedings by which the lawfulness of his detention shall be decided speedily by a court and his release ordered if the detention is not lawful” (Art. 5, Para 4). Additionally, article 4 of Protocol 4, prohibits the collective expulsion of aliens. (Art. 4, Protocol 4). 


\section{European Court of Human Rights}

The European Court was established in the European Convention on Human Rights. At present, following reforms that took place with the entry into force of Protocol 11 to the Convention for the Protection of Human Rights and Fundamental Freedoms (1994) in 1998, it is a full- time organ with competence to receive individual or state complaints regarding allegations of violations of the European Convention and to make binding decisions to states parties (or contracting parties) regarding such breaches. All member states of the Council of Europe must ratify the European Convention on Human Rights and are consequently subject to the European Court's jurisdiction. The court may also give advisory opinions on legal questions concerning the interpretation of the convention and protocols, though this later element has generally been a less prominent feature of the court's functioning (European Court of Human Rights 2008, “Historical Background”).

\section{Relevant Rulings of the European Court of Human Rights}

The European Court of Human Rights has made a number of rulings germane to the issue of migrant detention, including on:

\section{- $\quad$ Transit Zone Detention \\ - $\quad$ Lawfulness of Detention \\ - $\quad$ Detention for Deportation \\ - $\quad$ Prevention of Unauthorized Entry}

Transit Zone Detention. In 1996, the court ruled that the holding of persons in a transit zone at airports can be considered a deprivation of liberty and that its prolongation requires speedy review by the courts (Amuur v France 1996, paras. 43-49).

In the 1996 case, the court considered that French law at the time of the events under review by the court did not sufficiently guarantee the right to liberty. Thus, the court noted that this state of affairs did not allow "the ordinary courts to review the conditions under which aliens were held or, if necessary, to impose a limit on the administrative authorities as regards the length of time for which they were held. They did not provide for legal, humanitarian, and social assistance, nor did they lay down procedures and time-limits for access to such assistance so that asylum-seekers like the applicants could take the necessary steps" (Amuur v France 1996, para. 53).

Since this ruling, the issue of transit zone detention has been raised in other international fora. In his February 2008 report to the UN Human Right Council, for example, the Special Rapporteur on the Human Rights of Migrants stated: "Migrants and asylum-seekers are sometimes detained at airport transit zones and other points of entry, under no clear authority, either with the knowledge of government officials at the airport or simply on the instructions of airline companies before being returned to their countries. The difficulty or impossibility of reaching any outside assistance impedes the exercise of the right of the persons concerned to challenge the lawfulness of the State's decision to be detained and returned and to apply for asylum, even in the presence of legitimate claims” (Special Rapporteur on the Human Rights of Migrants Jorge Bustamante 2008a, para. 47). 
Review of Lawfulness of Detention. The European Court has held that detained persons must have the ability to obtain a periodic review by a court of the lawfulness of their detention, both at the time of the initial deprivation of liberty and in situations where new issues of lawfulness can arise (see, for example, Benjamin and Wilson v United Kingdom 2002, para. 33).

According to the court, the legal body that carries out the review must "exhibit the necessary judicial procedures and safeguards appropriate to the kind of deprivation of liberty in question, including most importantly independence of the executive and of the parties” (Benjamin and Wilson v United Kingdom 2002, para. 33; De Wilde, Ooms, and Versyp v. Belgium 1971, Series A no. 12, paras 76 and 78.)

Additionally, the court or body that carries out the review must have the competence to review the "lawfulness" of the detention and to order release if the detention is unlawful (Benjamin and Wilson v United Kingdom 2002, para. 34; Singh v. the United Kingdom 1996, para. 66.)

Detention for Deportation. Regarding the European Convention's article 5.1(f), which provides for "the lawful arrest or detention of a person to prevent his effecting an unauthorized entry into the country or of a person against whom action is being taken with a view to deportation or extradition," the court has considered that detention with a view to deportation can only be justified for as long as deportation proceedings are in progress and that deportation proceedings must be prosecuted with due diligence for the detention to be permissible (Chahal v. the United Kingdom 1996, para. 113.)

Prevention of Unauthorized Entry. In January 2008, the court for the first time examined the meaning of the phrase "to prevent his effecting an unauthorized entry into the country" present in the European Convention's article 5.1(f) (Saadi v the United Kingdom 2008). The case concerned the detention of an asylum seeker for seven days during the examination of his asylum application and the fact that the detention was not based on the asylum seeker's specific circumstances, such as an assessment of a risk of flight.

The court concluded that article 5.1(f) provides an exception to the general rule established by that article guaranteeing liberty and security of the person (Saadi $v$ the United Kingdom, para. 64). It considered that "until a State has 'authorized' entry to the country, any entry is 'unauthorized."” The court further considered that permitting detention only of a person who is "shown to be trying to evade entry restrictions" would be too narrow an interpretation of Article 5.1(f) and would furthermore be inconsistent with, among other, UNHCR Executive Committee 1986, Conclusion No. 44, and UNHCR's Guidelines as these "envisage the detention of asylum seekers in certain circumstances, for example while identity checks are taking place or when elements on which the asylum claim is based have to be determined" (Saadi $v$ the United Kingdom 2008, para. 65).

Nevertheless, the Court stressed that to be compatible with the European Convention any detention must be lawful and cannot be arbitrary (Saadi $v$ the United Kingdom 2008, para. 67). In the context of Article 5.1(f), the detention cannot be considered arbitrary if it is carried out in good faith by the authorities ordering the detention; it is closely connected with the purpose of the restriction permitted (i.e. preventing the unauthorized entry or person against whom action is being taken with a view to deportation); the place and conditions of 
detention are appropriate, in particular as this measure is "applicable not to those who have committed criminal offences but to aliens who, often fearing for their lives, have fled from their own country"; and the length of the detention does not exceed that reasonably required for the purpose pursued (Saadi $v$ the United Kingdom, para. 74).

The Saadi v the United Kingdom ruling proved controversial, especially among human rights advocates. In a press release, Amnesty International (AI) stated that the decision "appears to give states a broad discretion to detain people who are fleeing persecution, and are often in fear for their lives, for no other reason than the administrative convenience of the state in which they have sought asylum or international protection” (Amnesty International 2008a).

\section{European Convention for the Prevention of Torture and Inhuman or Degrading Treatment or Punishment (1987)}

The 1987 Convention for the Prevention of Torture and Inhuman or Degrading Treatment or Punishment established a system of visits to places of detention of states parties through its European Committee for the Prevention of Torture and Inhuman or Degrading Treatment or Punishment (CPT) with the purpose of protecting persons deprived of their liberty from torture and other inhuman or degrading treatment or punishment. All member states of the Council of Europe have ratified the European Convention for the Prevention of Torture.

According to its website, the CPT "visits places of detention (e.g. prisons and juvenile detention centres, police stations, holding centres for immigration detainees, and psychiatric hospitals), to see how persons deprived of their liberty are treated and, if necessary, to recommend improvements to States.” Details from CPT country visits are documented in reports and press releases, which are then posted on the CPT's website. These documents provide a good resource for those wishing to investigate state practices vis-à-vis all types of detention, including migration-related detention (CPT website 2008, "States: Documents and Visits”).

The CPT has developed standards relating to the treatment of persons deprived of their liberty, including (in section IV of the CPT Standards) provisions on foreign nationals detained under aliens legislation. These include the principles that when persons are held for extended periods they should be accommodated in centres specifically designed for that purpose and in adequate conditions; and that "Immigration detainees should-in the same way as other categories of persons deprived of their liberty-be entitled, as from the outset of their detention, to inform a person of their choice of their situation and to have access to a lawyer and a doctor. Further, they should be expressly informed, without delay and in a language they understand, of all their rights and of the procedure applicable to them" (CPT 2002, Section IV, paras. 29- 31). 


\section{Council of Europe Convention on Action against Trafficking in Human Beings (2005)}

The Convention on Action against Trafficking in Human Beings was adopted by the Council of Europe in 2005 and entered into force in February 2008. Article 14 of the convention provides that states parties shall issue a renewable residence permit to victims when either or both of the following conditions are met: a) "the competent authority considers that their stay is necessary owing to their personal situation; b) the competent authority considers that their stay is necessary for the purpose of their cooperation with the competent authorities in investigation or criminal proceedings.” (Art. 14.1). The same article provides that residence permits for child victims are to be issued in accordance with the best interests of the child and, where appropriate, renewed under the same conditions (Art. 14.2).

\section{Relevant European Union Directives}

Since 1999, the European Union has promoted a number of measures with a view to establishing common asylum and immigration policies. Among the initiatives have been the adoption of various policy directives and the conclusion of readmission agreements with nonEU countries. EU directives are legislative acts that require member states to achieve a specific result. However, directives normally give states a certain level of discretion in their implementation. The most relevant to the situation of non-citizens (or, as they are frequently termed in the EU context, "third country nationals”) are:

- $\quad$ Directive on Minimum Standards for the Reception of Asylum Seekers

- $\quad$ Directive on Minimum Standards on Procedures for Granting and Withdrawing Refugee Status

- "Return Directive"

Directive on Minimum Standards for the Reception of Asylum Seekers (European Union Council 2003). The 2003 EU Council Directive Laying Down Minimum Standards for the Reception of Asylum Seekers provides that EU member states "may confine an applicant (for asylum) to a particular place in accordance with their national law" when "it proves necessary, for example, for legal reasons or for reasons of public order" (European Union Council 2003, Article 7.3).

\section{Directive on Minimum Standards on Procedures in Member States for Granting and} Withdrawing Refugee Status (European Union Council 2005). The 2005 EU Council Directive on Minimum Standards on Procedures in Member States for Granting and Withdrawing Refugee Status states that member states "shall not hold a person in detention for the sole reason that he/she is an applicant for asylum" and that "Where an applicant for asylum is held in detention, Member States shall ensure that there is a possibility of speedy judicial review” (European Union Council 2005 Article 18).

“Return Directive” (European Union Council 2008). In 2005, the European Commission proposed a directive on common standards and procedures for the return of irregular migrants from non-EU countries. On 18 June 2008, after an at times divisive debate between EU members over the details of the directive, the European Parliament adopted a directive, titled Common Standards and Procedures in Member States for Returning Illegally Staying ThirdCountry Nationals (also known as the "Return Directive"). The final text of the provisional directive contained compromises on a number of controversial issues. These included: An obligation to impose an entry ban of up to five years if the illegally staying third-country 
national does not accept to return voluntarily (European Union Council 2008, Article 11); an obligation to provide illegally staying third-country nationals in pre-removal detention with legal aid in accordance with national legislation (European Union Council 2008, Article 13); and a maximum pre-removal detention period of up to 18 months, with an initial 6 months maximum but with the possibility for member states to extend detention for an additional 12 months in special circumstances (European Union Council 2008, Article 15).

This provisional directive proved highly controversial with an array of actors, including many non-EU states, UN bodies, and civil society groups. In June 2008, the Permanent Council of the Organization of American States (OAS) unanimously approved a resolution (CP/RES. $938(1654 / 08))$ requesting the OAS Secretary General to accompany a High Level Mission of OAS members to the European Union to hold a dialogue with their counterparts about the implications of the Return Directive (OAS Permanent Council 2008).

Ten of the Special Procedures of the UN Human Rights Council sent a letter to the Presidency of the Council of the European Union expressing concerns regarding the directive. The letter stated, "One principal concern relates to the detention regime pending removal procedures for irregular immigrants. The Directive envisages detention periods of up to 18 months, which appear to be excessive." It also noted that "irregular immigrants are not criminals. As a rule they should not be subjected to detention at all. Member States are obliged to explore the availability of alternatives to detention and detention must only be for the shortest possible period of time” (UN Press Release 2008).

Amnesty International stated, "We believe that the text approved on Wednesday 18 June by the European Parliament does not guarantee the return of irregular migrants in safety and dignity. On the contrary, an excessive period of detention of up to one and a half years as well as an EU-wide re-entry ban for those forcibly returned, risks lowering existing standards in the Member States and sets an extremely bad example to other regions in the world" (Amnesty International 2008b). 


\section{The Americas (the Inter-American Human Rights System)}

Created in 1948, the Organization of American States (OAS) promotes cooperation in the Americas on a number of issues, including strengthening democracy, promoting human rights, and confronting issues of concern such as poverty and corruption. Today, its members comprise all of the states of the Americas, including those of Latin America, the Caribbean, and North America. The two main bodies within the OAS concerned with human rights protection are the Inter-American Commission on Human Rights (IACHR) and the InterAmerican Court of Human Rights. The basic instruments for the promotion and protection of human rights within the organization's framework are the Charter of the Organization of American States (1948), the American Declaration on the Rights and Duties of Man (1948), and the American Convention on Human Rights (1969). Other relevant instruments adopted by countries in the region include the Cartagena Declaration on Refugees and the San José Declaration on Refugees and Internally Displaced Persons.

- $\quad$ American Declaration on the Rights and Duties of Man

- $\quad$ American Convention on Human Rights

- Inter-American Commission on Human Rights

- $\quad$ Relevant Decisions of the Inter-American Commission

- Inter-American Court of Human Rights

- $\quad$ Cartagena Declaration on Refugees

\section{American Declaration on the Rights and Duties of Man (1948)}

Article I of the American Declaration on the Rights and Duties of Man determines that "Every human being has the right to life, liberty, and the security of his person." The declaration also establishes that "No person may be deprived of his liberty except in the cases and according to the procedures established by pre-existing law. ... Every individual who has been deprived of his liberty has the right to have the legality of his detention ascertained without delay by a court, and the right to be tried without undue delay or, otherwise, to be released. He also has the right to humane treatment during the time he is in custody" (Article XXV). Article XXVII protects the right to seek and receive asylum.

\section{American Convention on Human Rights (1969)}

The American Convention on Human Rights protects the right to humane treatment and determines that "All persons deprived of their liberty shall be treated with respect for the inherent dignity of the human person. (Art. 5.2). Article 7 of the convention, which protects the right to personal liberty, determines that:

1. Every person has the right to personal liberty and security.

2. No one shall be deprived of his physical liberty except for the reasons and under the conditions established beforehand by the constitution of the State Party concerned or by a law established pursuant thereto.

3. No one shall be subject to arbitrary arrest or imprisonment.

4. Anyone who is detained shall be informed of the reasons for his detention and shall be promptly notified of the charge or charges against him. 
5. Any person detained shall be brought promptly before a judge or other officer authorized by law to exercise judicial power and shall be entitled to trial within a reasonable time or to be released without prejudice to the continuation of the proceedings. His release may be subject to guarantees to assure his appearance for trial.

6. Anyone who is deprived of his liberty shall be entitled to recourse to a competent court, in order that the court may decide without delay on the lawfulness of his arrest or detention and order his release if the arrest or detention is unlawful. In States Parties whose laws provide that anyone who believes himself to be threatened with deprivation of his liberty is entitled to recourse to a competent court in order that it may decide on the lawfulness of such threat, this remedy may not be restricted or abolished. The interested party or another person in his behalf is entitled to seek these remedies (Art. 7).

Additionally, Article 22 of the American Convention, which establishes the right to freedom of movement, states in paragraphs 6-9 that:

6. An alien lawfully in the territory of a State Party to this Convention may be expelled from it only pursuant to a decision reached in accordance with law.

7. Every person has the right to seek and be granted asylum in a foreign territory, in accordance with the legislation of the state and international conventions, in the event he is being pursued for political offenses or related common crimes.

8. In no case may an alien be deported or returned to a country, regardless of whether or not it is his country of origin, if in that country his right to life or personal freedom is in danger of being violated because of his race, nationality, religion, social status, or political opinions.

9. The collective expulsion of aliens is prohibited (Art.22, Paras. 6-9).

\section{Inter-American Commission on Human Rights (IACHR)}

The Inter-American Commission on Human Rights, created in 1959, is competent to promote the observance and defence of human rights in all member states of the OAS. The InterAmerican Commission applies the American Declaration on the Rights and Duties of Man (1948) to all OAS member states despite the fact that it was not originally adopted as a legally binding treaty. This is done because the system's monitoring bodies consider the American Declaration to be a source of international obligations for all member states. The American Convention on Human Rights (1969), on the other hand, is applied only to those states that have ratified it (see IACHR website, "Basic Documents: Introduction”).

The Commission's mandate is found in the Charter of the OAS (1948) and the American Convention on Human Rights (1969). The IACHR meets in ordinary and special sessions several times a year. The commission is competent to receive and investigate individual petitions that allege violations of either the American Declaration or the American Convention; submit cases to the Inter-American Court and appear before the court; request advisory opinions from the court regarding questions of interpretation of the American Convention; monitor the human rights situation in OAS member states and publish special reports; and carry out visits to countries in the Americas, which normally entails the preparation of a report (see Inter-American Commission on Human Rights 2008 website, "What is the IACHR").

The IACHR also has established special enquiry mechanisms (Special Rapporteurships) on specific themes, including Special Rapporteurships on Migrant Workers and their Families 
and the Rights of Persons Deprived of Liberty. Both mechanisms have carried out visits to OAS member states.

The Rapporteurship on Migrant Workers, which generally has had a greater opportunity to examine the specific question of migrants in detention, has undertaken visits to and issued reports on the United States, Costa Rica, Guatemala, and Mexico.

In March 2008, the IACHR adopted the "Principles and Best Practices for the Protection of Persons Deprived of Liberty in the Americas” (Principios y Buenas Practicas sobre la Proteccion de las Personas Privadas de Libertad en las Américas 2008). The principles detail minimum standards applicable for the protection of persons in detention in the Americas, including the right to be treated humanely; the right to have timely judicial or equivalent review; the right to appeal; the right to legal assistance; and the right to have contact with the outside world. The principles also establish that asylum seekers or persons detained because of migration legislation should not be held in the same places of detention used to confine persons convicted or accused of criminal offences.

\section{Relevant Decisions of the Inter-American Commission}

Certain decisions by the IACHR have addressed issues of non-citizens and asylum seekers that can be relevant to the situation of immigration-related detention.

Regarding non-citizens in administrative detention for security reasons, the commission found that the following requirements must be satisfied: "[F]irst preventive detention, for any reason of public security, must be based on the grounds and procedures set forth in law; second, it may not be arbitrary; and third, supervisory judicial control must be available without delay. In situations of continuing detention, this necessarily includes supervision at regular intervals” (Rafael Ferrer-Mazorra and other v the United States of America 2001, para. 212).

The commission also determined that detention review proceedings must comply with minimum standards of procedural fairness. The decision-maker must satisfy criteria established in article XXV of the American Declaration on prevailing standards of impartiality; the detainee must be given an opportunity to present evidence; and the detainee must have an opportunity to be represented by counsel or other representative (Rafael FerrerMazorra and other $v$ the United States of America, April 4, 2001, para. 213).

Regarding the case of Haitian asylum seekers interdicted at sea and returned to Haiti the commission concluded that "the act of interdicting the Haitians in vessels on the high seas constituted a breach of the Haitians' right to liberty within the terms of Article I of the American Declaration” (Haitian Boat People (United States of America) 1997, para. 169). 


\section{Inter-American Court of Human Rights}

The Inter-American Court was created by the American Convention on Human Rights (1969) and can issue binding judgments in cases alleging violations of the convention. The court's jurisdiction to receive individual (contentious) cases is optional for states parties to the American Convention. The Court also issues advisory opinions on various aspects of human rights and the American Convention or other treaties concerning the protection of human rights in the American states.

In 1999, the Court issued an advisory opinion on the rights to information on consular assistance. The court conclude: "That Article 36 of the Vienna Convention on Consular Relations (1963) confers rights upon detained foreign nationals, among them the right to information on consular assistance, and that said rights carry with them correlative obligations for the host State” (Inter-American Court of Human Rights 1999).

In its advisory opinion on the rights of undocumented migrants, the Inter-American Court ruled that "the right to due process of law should be recognized within the framework of the minimum guarantees that should be provided to all migrants, irrespective of their migratory status. The broad scope of the preservation of due process applies not only ratione materiae but also ratione personae, without any discrimination" (Inter-American Court of Human Rights 2003).

\section{Cartagena Declaration on Refugees (1984)}

An important instrument adopted at the Latin American level is the Cartagena Declaration on Refugees. The declaration was adopted in 1984 by a group of governmental experts and eminent jurists from the region and focused on the situation of Central American refugees. The declaration sets forth a broader definition of a "refugee" than that of the 1951 Convention relating to the Status of Refugees. In addition to the categories of persons covered in the Refugee Convention, the Cartagena Declaration states that refugees include persons who have fled their countries because their lives, safety, or freedom have been threatened by generalized violence, foreign aggression, internal conflicts, massive violation of human rights, or other circumstances that have seriously disturbed public order.

1994, the San José Declaration on Refugees and Internally Displaced Persons was adopted by participants at a colloquium in San José, Costa Rica, commemorating the 10th anniversary of the Cartagena Declaration. The San José Declaration re-affirms the importance of the Cartagena Declaration as a protection tool in Latin America and refers to the need to address the plight of internally displaced persons in the region. 


\section{Other Regional Systems}

- Africa

- $\quad$ League of Arab States

\section{Africa}

The regional African human rights system was created within the framework of the Organization of African Unity (OAU), today African Union (AU). It is primarily based on the African Charter on Human and Peoples' Rights (1981) (the African or Banjul Charter), which was adopted in 1981 and came into force in 1986.

Article 6 of the charter protects the rights to liberty and security and determines: "Every individual shall have the right to liberty and to the security of his person. No one may be deprived of his freedom except for reasons and conditions previously laid down by law. In particular, no one may be arbitrarily arrested or detained" (African Charter on Human and Peoples’ Rights 1981, Art. 6).

Article 12 of the charter protects the right to asylum and the rights of persons legally in the territory of a state party not to be expelled in the absence of a decision taken in accordance with the law. It also prohibits mass expulsion of non-nationals, determining that "Mass expulsion shall be that which is aimed at national, racial, ethnic, or religious groups" (African Charter on Human and Peoples’ Rights 1981, Art. 12).

In June 1998, the Protocol to the African Charter on Human and Peoples' Rights on the Establishment of an African Court on Human and Peoples' Rights (1998) was adopted to complement the work of the African Commission on Human and Peoples' Rights. The protocol entered into force in 2004 and the Judges of the Court were elected in January 2006.

The African Commission on Human and Peoples’ Rights was established by the African Charter on Human and Peoples' Rights. The Commission meets twice a year, either in the Gambia or other member state of the AU.

The African Commission's overall mandate is to promote and protect human and peoples' rights and interpret the African Charter on Human and Peoples' Rights. More specifically the African Commission can collect documents, undertake studies, formulate and lay down principles and rules, and cooperate with other African countries or international institutions involved in the protection of human and peoples' rights. In carrying out its functions, the commission may carry out country visits. It has also established a number of inquiry mechanisms (Rapporteurships) on specific themes. Similar to the committees set up under a number of the UN human rights treaties, the commission also considers the periodic reports of states parties on the legislative or other measures adopted to give effect to the rights and freedoms recognized and guaranteed in the African Charter on Human and Peoples' Rights (1981).

Additionally, the commission can receive communications from states parties, individuals, or NGOs regarding allegations of violations of the rights protected under the charter. With the entry into force of the Protocol on the Establishment of an African Court on Human and Peoples' Rights, the commission may also submit cases to the court. 
Two of the commissions' special mechanisms can be relevant to the situation of non-citizens in detention: the Special Rapporteur on Refugees, Asylum Seekers, Migrants, and Internally Displaced Persons and Migrants in Africa, created in 2004; and the Special Rapporteur on Prisons and Conditions of Detention in Africa, created in 1996.

As of mid-2008, the Rapporteur on Prisons had issued reports based on visits to Cameroon, Ethiopia, and South Africa. The report on South Africa includes a section on the rapporteur's visit to the Lindela Repatriation Center and recommends that the government provide detained undocumented migrants the opportunity to challenge their arrest and/or detention in a court of law and that measures be adopted to ensure that such persons are repatriated within a certain period of time (Special Rapporteur on Prisons and Conditions of Detention in Africa 2004, p. 65, para. k).

Lastly, there is the OAU Convention Governing the Specific Aspects of Refugee Problems in Africa (1969), adopted in 1969, which expanded the definition of a refugee. Under this convention, refugees include not only persons who leave their country as a result of a wellfounded fear of persecution, but also those who flee "owing to external aggression, occupation, foreign domination, or events seriously disturbing public order in either part or the whole of his country of origin or nationality" (Convention Governing the Specific Aspects of Refugee Problems in Africa 1969, Art. 1.2). The OAU Convention requires that member states of the OAU "use their best endeavours to receive refugees and to secure the settlement of those refugees” (Convention Governing the Specific Aspects of Refugee Problems in Africa 1969, Art. 2.1). 


\section{League of Arab States}

The Arab Charter on Human Rights (Revised) (2004) was adopted in 2004 by the League of Arab States, which as of mid-2008 included 22 states from the Middle East and North and Northeast Africa. The 2004 charter, which replaced the 1994 Arab Charter, entered into force in 2008. It defines and protects a broad range of civil and political rights, as well as economic, social, and cultural rights. It also creates an Arab Human Rights Committee competent to receive and examine reports submitted by states parties on measures adopted to ensure the implementation of the rights protected under the charter.

Article 14 of the Arab Charter protects the right to liberty and security of the person and determines that: everyone has the right to liberty and security of person and no one shall be subjected to arbitrary arrest, search or detention without a legal warrant (Arab Charter on Human Rights (Revised) 2004, Art. 14.1); no one shall be deprived of his liberty except on such grounds and in such circumstances as are determined by law and in accordance with such procedure as is established thereby (Arab Charter on Human Rights (Revised) 2004, Art. 14.2); anyone who is arrested shall be informed, at the time of arrest, in a language that he understands, of the reasons for his arrest and shall be promptly informed of any charges against him and be entitled to contact his family members (Arab Charter on Human Rights (Revised) 2004, Art. 14.3); anyone who is deprived of his liberty by arrest or detention shall have the right to request a medical examination and must be informed of that right (Arab Charter on Human Rights (Revised) 2004, Art. 14.4); anyone who is deprived of his liberty by arrest or detention shall be entitled to petition a competent court in order that it may decide without delay on the lawfulness of his arrest or detention and order his release if the arrest or detention is unlawful (Arab Charter on Human Rights (Revised) 2004, Art. 14.6).

The charter also determines that all persons deprived of their liberty are to be treated humanely (Arab Charter on Human Rights (Revised) 2004, Art. Art. 20). It stipulates that non-citizens lawfully in the territory of a state party may not be expelled "other than in pursuance of a decision reached in accordance with law and after that person has been allowed to submit a petition to the competent authority, unless compelling reasons of national security preclude it.” The charter prohibits the collective expulsions of aliens (Arab Charter on Human Rights (Revised) 2004, Art. Art. 26) and guarantees the right to seek asylum (Arab Charter on Human Rights (Revised) 2004, Art. Art.28). 


\section{Additional Sources}

1. Conventions of the International Labor Organization

2. International Humanitarian Law

\section{Conventions of the International Labor Organization}

Established in 1919 as a part of the Treaty of Versaille ending World War I, the International Labor Organization is mandated to promote social justice and develop standards on workers rights. The ILO has adopted more than 180 conventions covering a broad range of issues, including the right to work, the right to collective bargaining, child labor, work-place discrimination, and forced labor. Many of the rights recognized in these conventions are also protected in core UN instruments and human rights treaties, such as the Universal Declaration of Human Rights; the International Covenant on Economic, Social, and Cultural Rights; the Convention on the Rights of the Child; and the International Convention on the Protection of the Rights of All Migrant Workers and Members of Their Families.

Among the ILO conventions that can have relevance to the detention and deportation of migrants are: the Forced Labor Convention of 1930 (also known as Convention 29, or the Convention concerning Forced or Compulsory Labor), which is one of the "fundamental ILO conventions"; the Migration for Employment Convention of 1949 (Convention 97, Convention concerning Migration for Employment ); the Migrant Workers Convention of 1975 (Convention 143, Convention concerning Migrations in Abusive Conditions and the Promotion of Equality of Opportunity and Treatment of Migrant Workers); and the Private Employment Agencies Convention of 1997 (Convention 181, Convention concerning Private Employment Agencies).

The Forced Labor Convention of 1930 is one of the eight treaties that are considered “fundamental ILO conventions," which were established as such in the ILO's 1998 Declaration on Fundamental Principles and Rights at Work. An intent of the declaration is to "affirm that the principles reflected in the fundamental conventions express core principles of international labor law, which are binding on all ILO member states, whether or not they have become parties to relevant conventions” (Marks and Clapham 2005, p. 445).

In a 2005 follow-up report to the 1998 declaration, titled A Global Alliance against Forced Labour: Global Report under the Follow-up to the ILO Declaration on Fundamental Principles and Rights at Work, the ILO highlights the use of detention and deportation in the context of the forced labor of migrant workers. It states, "The precarious legal status of millions of irregular migrant women and men makes them particularly vulnerable to coercion, because of the additional and ever-present threat of denunciation to the authorities. Victims can be faced with the difficult choice between accepting highly exploitative conditions of work and running the risk of deportation to their home countries if they seek redress" (ILO 2005, p. 2). An illustrative case of this sort of forced labor situation with respect to migrant workers is the situation of some imported domestic laborers in the Gulf states. $^{3}$

\footnotetext{
${ }^{3}$ See, for instance, the Global Detention Project's profile on Bahrain, September 2009, http://www.globaldetentionproject.org/countries/middle-east/bahrain/introduction.html.
} 
The 2005 report also notes that detention can be an indication of forced labor, in particular, "Physical confinement in the work location-in prison or in private detention" (ibid, p. 6). It clarifies that although there is an exception to the prohibition against forced labor in the case of people imprisoned because of criminal convictions, this exception does not apply to people in administrative detention (the form of confinement used for most migrant detainees) and that there are specific protections for people held in privately-run prisons, which are increasingly used by states for the purposes of immigration detention. ${ }^{4}$ The report states, "The ILO instruments provide for exceptions to the prohibition of exacting forced labour, in the case of prisoners who have been duly sentenced by a court of law. Persons under administrative detention are exempt from forced or compulsory labour; and there are specific guarantees of protection for prisoners placed at the disposal of private individuals, companies, or associations, including those confined in private prisons. Yet of the approximately 8 million recognized prisoners worldwide- not to mention those in administrative or other forms of detention-only some 150,000 are in private prisons, and no figures are available as to those who might be working for private employers” (ibid, p. 27).

In this context, of particular relevance, especially to the situation of migrant workers, is the Forced Labor Convention's Article 1, which affirms that member states undertake "to suppress the use of forced or compulsory labor." Article 2 defines forced labor as "all work or service which is extracted from any person under the menace of any penalty and for which the said person has not offered himself voluntarily," with a number of exceptions, including military service, civic obligations, and work stemming from a conviction in court of law (as long as the person "is not hired to or placed at the disposal" of private entities). In addition, Article 4 provides that authorities "shall not impose or permit the imposition of forced or compulsory labor for the benefit of private individuals, companies, or associations."

Two ILO conventions specifically address the rights of migrants, the Migration for Employment Convention of 1949 and the Migrant Workers Convention of 1975. Key aspects of the 1949 convention are its articulation of principles on conditions governing the recruitment of migrant workers, their equal treatment, their right to collective bargaining, among other rights (Cholewinski 2005). Of particular salience to the issue of migrationrelated detention is Article 8 of the 1949 convention, which stipulates, “A migrant for employment who has been admitted on a permanent basis and the members of his family who have been authorized to accompany or join him shall not be returned to their territory of origin or the territory from which they emigrated because the migrant is unable to follow his occupation by reason of illness contracted or injury sustained subsequent to entry, unless the person concerned so desires or an international agreement to which the Member is a party so provides.”

The 1975 Migrant Workers Convention is more expansive in scope than the 1949 convention, in particular with respect to irregular migrants and human trafficking. "Adopted at a time when particular migration abuses, such as the smuggling and trafficking of migrant workers, were attracting the attention of the international community ... this instrument devotes a whole section to irregular migration and to interstate collaborative measures considered necessary to prevent it” (Cholewinski 2005). Article 1 stipulates, "Each Member for which this Convention is in force undertakes to respect the basic human rights of all migrant workers.”

\footnotetext{
${ }^{4}$ See Michael Flynn and Cecilia Cannon, "The Privatization of Immigration Detention: Towards a Global View," Global Detention Project working paper, September 2009,

http://www.globaldetentionproject.org/fileadmin/docs/GDP PrivatizationPaper Final5.pdf.
} 
A key aim of the 1975 convention is to suppress illegal and/or clandestine labor migration "in order to prevent and to eliminate" abuses (Art. 3). This aspect of the convention is directed particularly at those who smuggle and/or employ undocumented migrant workers. Article 3 stipulates that member states shall adopt necessary measures "against the organizers of illicit or clandestine movements of migrants for employment departing from, passing through or arriving in its territory, and against those who employ workers who have immigrated in illegal conditions.”

With respect to the rights of irregular migrants, including those subject to detention or deportation, the 1975 convention provides, "Without prejudice to measures designed to control movements of migrants for employment by ensuring that migrant workers enter national territory and are admitted to employment in conformity with the relevant laws and regulations, the migrant worker shall, in cases in which these laws and regulations have not been respected and in which his position cannot be regularized, enjoy equality of treatment for himself and his family in respect of rights arising out of past employment as regards remuneration, social security, and other benefits” (Art. 9). Article 9 also provides that an illegally residing worker shall "have the possibility of presenting his case to a competent body, either himself or through a representative" and that "in case of expulsion of the worker or his family, the cost shall not be borne by them."

Lastly, of indirect relevance to migration-related detention, particularly with respect to abuses in the recruitment of migrant workers, is the Private Employment Agencies Convention, which was adopted in 1997 out of recognition that for-profit employment agencies increasingly play a role in labor markets. Article 8 stipulates that member states shall "adopt all necessary and appropriate measures ... to provide adequate protection for and prevent abuses of migrant workers recruited or placed in its territory by private employment agencies. These shall include laws or regulations which provide for penalties, including prohibition of those private employment agencies which engage in fraudulent practices.” 


\section{International Humanitarian Law}

International humanitarian law (IHL) is a set of norms established in customary international law and a number of international conventions_-including the Hague Conventions of 1899 and the four Geneva Conventions of 1949 as well as their additional protocols of 1977-that are commonly referred to as "the law of war or the law of armed conflict." According to the International Committee of the Red Cross (ICRC), IHL seeks, "for humanitarian reasons, to limit the effects of armed conflict. It protects persons who are not or are no longer participating in the hostilities and restricts the means and methods of warfare” (ICRC 2004).

Although IHL does not directly address migration-related detention, many of the norms and legal interpretations that emerge from this body of law cover detention, in particular administrative detention, and provide useful guidelines for understanding key issues that arise in migration-related detention situations. IHL has also informed relevant human rights conventions, like the Refugee Convention. "One of the cardinal principles of international refugee law, the exclusively civilian character of refugee camps and settlements and, more broadly, of asylum, has been shaped and permeated by a founding principle of international humanitarian law, namely, the principle of distinction” between combatants and civilians (Jaquemet 2001).

Among the concepts developed in international humanitarian law that are reflected in human rights norms relevant to migration-related detention are the notion of "interned," which closely resembles "administrative detention," and access to places of detention by independent third parties (for a detailed discussion of IHL norms with respect to internment, see Pejic 2005).

The Commentary to Protocol I to the Geneva Conventions defines "interned" as the "deprivation of liberty ordered by the executive authorities when no specific criminal charge is made against the individual concerned" (ICRC 1977).

The 1949 Convention relative to the Protection of Civilian Persons in Time of War, (Convention IV) stipulates that the ICRC "shall have permission to go to all places where protected persons are, particularly to places of internment, detention, and work. They shall have access to all premises occupied by protected persons and shall be able to interview the latter without witnesses, personally or through an interpreter. Such visits may not be prohibited except for reasons of imperative military necessity, and then only as an exceptional and temporary measure. Their duration and frequency shall not be restricted. Such representatives and delegates shall have full liberty to select the places they wish to visit” (Art. 143).

The term "protected person" in the convention refers uniquely to "those who, at a given moment and in any manner whatsoever, find themselves, in case of a conflict or occupation, in the hands of a Party to the conflict or Occupying Power of which they are not nationals" (Art. 4). However, the notion of access by independent third parties to places of detention has been used in subsequent human rights conventions, in particular the 2002 Optional Protocol to the Convention Against Torture (OPCAT), which seeks to prevent torture and ill-treatment through the establishment of a system of regular visits by independent international and national bodies to places of detention. All places of detention under the jurisdiction and control of states parties are subject to visits under this protocol, including sites where noncitizens are held in administrative detention. 
The Working Group on Arbitrary Detention has also highlighted ICRC's role in visiting places of detention, including those used to hold asylum seekers. In a 2000 report to the Commission on Human Rights, the Working Group enumerated several "principles” with respect to the administrative detention of asylum seekers, including that "The Office of the United Nations High Commissioner for Refugees (UNHCR), the International Committee of the Red Cross (ICRC) and, where appropriate, duly authorized non-governmental organizations must be allowed access to the places of custody” (WGAD 1999).

Lastly, Convention IV provides additional protections for refugees. While Article 9 of the Refugee Convention allows states to derogate from the protections provided refugees during "time of war or other grave and exceptional circumstances," Convention IV "contains important complementary safeguards ... [and] urges States to show the greatest restraint in applying special measures to protected persons” (Jaquemet 2001). 


\section{References}

\section{Alphabetical Listing \\ 2. Official Documents}

\section{Alphabetical Listing}

A. v. Australia. 1997. Human Rights Committee. Communication No. 560/1993, Views of 3 April 1997. http://tb.ohchr.org/default.aspx (accessed 2 October 2008).

African Commission on Human and Peoples' Rights. www.achpr.org (accessed 11 April 2008).

African [Banjul] Charter on Human and Peoples' Rights. 1981. Organisation of African Unity. Adopted June 27, 1981, OAU Doc. CAB/LEG/67/3 rev. 5, 21 I.L.M. 58 (1982), entered into force Oct. 21, 1986: [excerpts]. University of Minnesota Human Rights Library. http://www1.umn.edu/humanrts/instree/z1afchar.htm (accessed 24 October 2008).

Arab Charter on Human Rights (Revised). 2004. League of Arab States. May 22, 2004, reprinted in 12 Int'l Hum. Rts. Rep. 893 (2005), entered into force March 15, 2008. University of Minnesota Human Rights Library. http://www1.umn.edu/humanrts/instree/loas2005.html?msource=UNWDEC19001\&tr=y\&aui $\mathrm{d}=3337655$ (accessed 24 October 2008).

African Commission on Human and Peoples’ Rights. 1991-2007. "Final Communiqués and other Documentation of the African Commission on Human and Peoples' Rights (Sessions 1991-2007).” University of Minnesota Human Rights Library. www1.umn.edu/humanrts/africa/communiques.html (accessed 14 April 2008).

American Convention on Human Rights. 1969. Organisation of American States (OAS). O.A.S. Treaty Series No. 36, 1144 U.N.T.S. 123. Entered into force July 18, 1978. Reprinted in Basic Documents Pertaining to Human Rights in the Inter-American System.

OEA/Ser.L.V/II.82 doc.6 rev.1 at 25 (1992). University of Minnesota Human Rights Library. http://www1.umn.edu/humanrts/oasinstr/zoas3con.htm (accessed 24 October 2008).

American Declaration on the Rights and Duties of Man. 1948. Organisation of American States (OAS). Res. XXX, adopted by the Ninth International Conference of American States (1948). Reprinted in Basic Documents Pertaining to Human Rights in the Inter-American System. OEA/Ser.L.V/II.82 doc.6 rev.1 at 17 (1992). University of Minnesota Human Rights Library, http://www1.umn.edu/humanrts/oasinstr/zoas2dec.htm (accessed 24 October 2008).

Amnesty International. 2007. "Migration-Related Detention: A research guide on human rights standards relevant to the detention of migrants, asylum-seekers and refugees.” Amnesty International. November 2007. www.amnesty.org/en/library/info/POL33/005/2007 (accessed 11 April 2008).

Amnesty International. 2008a. "United Kingdom: detention of asylum-seekers must be the exception, not the rule.” Amnesty International. AI EUR 45/002/2008 (Public). January 2008. www.amnestyusa.org/document.php (accessed 3 April 2008). 
Amnesty International. 2008b. "EU return directive affects dignity and security of irregular migrants.” Amnesty International. 4 July 2008. http://www.amnesty.org/en/news-andupdates/EU-return-directive-affects-dignity-security-irregular-migrants-20080704 (accessed August 1, 2008).

Amuur v France. 1996. European Court of Human Rights. Judgment of 25 June 1996. Reports 1996-III. cmiskp.echr.coe.int/tkp197/search.asp (accessed 15 April 2008).

Bakhtiyari v. Australia. 2003. Human Rights Committee. Communication No.1069/2002, Views of 29 October 2003. http://tb.ohchr.org/default.aspx (access 2 October 2008).

Benjamin and Wilson v United Kingdom. 2002. European Court of Human Rights., judgment of 26 September 2002. cmiskp.echr.coe.int/tkp197/search.asp (accessed 15 April 2008).

Body of Principles for the Protection of All Persons under Any Form of Detention or Imprisonment. 1988. UN General Assembly. Adopted by General Assembly resolution 43/173. 9 December 1988. http://www.unhchr.ch/html/menu3/b/h_comp36.htm (accessed 21 October 2008).

C v Australia. 2002. Human Rights Committee. Communication No. 900/1999, Views of 28 October 2002. http://tb.ohchr.org/default.aspx (access 2 October 2008).

Cartagena Declaration on Refugees. 1984. Inter-American Commission on Human Rights. 22 November 1984 in Annual Report of the Inter-American Commission on Human Rights, OAS Doc. OEA/Ser.L/V/II.66/doc.10, rev. 1, at 190-93 (1984-85).

http://www1.umn.edu/humanrts/instree/cartagena1984.html (accessed 24 October 2008).

Celepli v. Sweden. 1994. Human Rights Committee. Communication No. 456/1991, Views of 18 July 1994. http://tb.ohchr.org/default.aspx (access 2 October 2008).

Chahal v. the United Kingdom. 1996. European Court of Human Rights. Judgment of 15 November 1996. Reports 1996-V. cmiskp.echr.coe.int/tkp197/search.asp (accessed 15 April 2008).

Charter of the Organization of American States. 1948. Organization of American States. Washington DC. http://www.oas.org/juridico/english/charter.html (accessed 19 November 2008).

Cholewinski, Ryszard. 2005. "Protecting Migrant Workers in a Globalized World.” Migration Policy Institute. March 2005.

Commission on Human Rights resolution 1997/50. Question of Arbitrary Detention. Adopted 15 April 1997.

Committee Against Torture. 2006. “Concluding Observations: France.” UN Office of the High Commissioner for Human Rights. CAT/C/FRA/CO/3. 3 April 2006. tb.ohchr.org/default.aspx (accessed 15 April 2008).

Committee Against Torture. 2007a. "Concluding Observations: Japan." UN Office of the High Commissioner for Human Rights. CAT/C/JPN/CO/1, 3 August 2007. tb.ohchr.org/default.aspx (accessed 15 April 2008). 
Committee Against Torture. 2007b. "Concluding Observations: Ukraine.” UN Office of the High Commissioner for Human Rights. CAT/C/UKR/CO/5. 3 August 2007. tb.ohchr.org/default.aspx (accessed 15 April 2008).

Committee on the Elimination of Discrimination Against Women. 2006. "Concluding Comments: Malaysia.” UN Office of the High Commissioner for Human Rights.

CEDAW/C/MYS/CO/2. 31 May 2006. tb.ohchr.org/default.aspx (accessed April 15, 2008).

Committee on the Elimination of Racial Discrimination (CERD). 2004. "General

Recommendation No.30: Discrimination Against Non Citizens (General Comments).” UN

Office of the High Commissioner for Human Rights. 1 October 2004.

www.unhchr.ch/tbs/doc.nsf/(Symbol)/e3980a673769e229c1256f8d0057cd3d (accessed 15

April 2008).

Committee on the Elimination of Racial Discrimination (CERD). 2006. "Concluding Observations: South Africa." UN Office of the High Commissioner for Human Rights.

CERD/C/ZAF/CO/3. 19 October 2006. tb.ohchr.org/default.aspx (accessed April 15, 2008).

Committee on Migrant Workers. 2006. "Concluding Observations: Mexico.” UN Office of the High Commissioner for Human Rights. CMW/C/MEX/CO/1. 20 December 2006. tb.ohchr.org/default.aspx (accessed 15 April 2008).

Committee on the Rights of the Child (CRC). 2005a. "General Comment $\mathrm{N}^{\circ}$ 6, The Treatment of Unaccompanied and Separated Children Outside their Country of Origin." UN Office of the High Commissioner for Human Rights. CRC/GC/2005/6. 1 September 2005. www2.ohchr.org/english/bodies/crc/comments.htm (accessed 15 April 2008).

Committee on the Rights of the Child (CRC). 2005b. "Concluding Observations: Australia." CRC/C/15/Add.268. UN Office of the High Commissioner for Human Rights. 20 October 2005. tb.ohchr.org/default.aspx (accessed 15 April 2008).

Committee on the Rights of the Child (CRC). 2007. "Concluding Observations on the Report Submitted under the Optional Protocol to the Convention on the Rights of the Child on the Sale of Children, Child Prostitution and Child Pornography (OPSC): France." UN Office of the High Commissioner for Human Rights. CRC/C/OPSC/FRA/CO/1. 15 October 2007. tb.ohchr.org/default.aspx (accessed 15 April 2008).

Convention on Action against Trafficking in Human Beings. 2005. Council of Europe. Council of Europe Treaty Series - No. 197, 2005.

http://www.coe.int/t/dg2/trafficking/campaign/Docs/Convntn/CETS197_en.asp \#TopOfPage (accessed 24 October 2008).

Convention concerning Forced or Compulsory Labor (Convention 29, Forced Labor Convention). Adopted 28 June 1930. International Labor Organization. Geneva, Switzerland. http://www.ilo.org/ilolex/cgi-lex/convde.pl?C029

Convention concerning Migration for Employment (Revised 1949) (Convention 97, Migration for Employment Convention). Adopted 1 July 1949. International Labor Organization. Geneva, Switzerland. http://www.ilo.org/ilolex/cgi-lex/convde.pl?C097 
Convention concerning Migrations in Abusive Conditions and the Promotion of Equality of Opportunity and Treatment of Migrant Workers (Convention 143, Migrant Workers (Supplementary Provisions) Convention). Adopted 24 June 1975. International Labor Organization. Geneva, Switzerland. http://www.ilo.org/ilolex/cgi-lex/convde.pl?C143

Convention concerning Private Employment Agencies (Convention 181, Private Employment Agencies Convention). Adopted 19 June 1997. International Labor Organization. Geneva, Switzerland. http://www.ilo.org/ilolex/cgi-lex/convde.pl?C181

Convention against Torture and Other Cruel, Inhuman or Degrading Treatment or Punishment. 1984. UN Office for the High Commissioner for Human Rights. Adopted by General Assembly resolution 39/46, 10 December 1984. Entry into force 26 June 1987. http://www.unhchr.ch/html/menu3/b/h_cat39.htm (accessed 20 October 2008).

Convention on the Elimination of All Forms of Discrimination against Women (CEDAW). 1979. UN Division for the Advancement of Women. Adopted 1979 by the UN General Assembly. http://www.un.org/womenwatch/daw/cedaw/cedaw.htm (accessed 20 October 2008).

Convention Governing the Specific Aspects of Refugee Problems in Africa. 1969.

Organisation of African Unity. Adopted 1969. http://www.africa-

union.org/Official_documents/Treaties_\%20Conventions_\%20Protocols/Refugee_Conventio n.pdf (accessed 24 October 2008).

Convention for the Protection of Human Rights and Fundamental Freedoms as amended by Protocol No. 11. 1950. Council of Europe. Rome, 4.XI.1950.

http://conventions.coe.int/treaty/EN/Treaties/html/005.htm (accessed 23 October 2008).

Convention Relating to the Status of Refugees (See also UN Refugee Convention). 1951. UN High Commissioner for Refugees. Geneva. http://www.unhcr.org/cgi-

bin/texis/vtx/protect?id=3c0762ea4 (accessed 20 October 2008).

Convention on the Rights of the Child. 1989. Committee on the Rights of the Child, UN Office for the High Commissioner for Human Rights. Adopted by General Assembly resolution 44/25. 20 November 1989. Entry into force 2 September 1990.

http://www.unhchr.ch/html/menu3/b/k2crc.htm (accessed 20 October 2008)

Council of Europe. Undated. "Human Rights.”

http://web.archive.org/web/20080209231216/http://www.coe.int/T/E/Human_rights/ (accessed 16 April 2008).

Declaration on the Human Rights of Individuals Who are not Nationals of the Country in which They Live (DHRINNC). 1985. UN General Assembly. Adopted by General Assembly resolution 40/144 of 13 December 1985. http://www.unhchr.ch/html/menu3/b/o_nonnat.htm (accessed 21 October 2008).

De Wilde, Ooms and Versyp v. Belgium. 1971. European Court of Human Rights. Judgment of 18 June 1971. Series A no. 12. cmiskp.echr.coe.int/tkp197/search.asp (accessed 15 April 2008). 
European Committee for the Prevention of Torture and Inhuman or Degrading Treatment or Punishment (CPT). 2008. Website. www.cpt.coe.int/en/about.htm (accessed 1 April 2008).

European Committee for the Prevention of Torture and Inhuman or Degrading Treatment or Punishment (CPT). 2002. “CPT Standards.” European Committee for the Prevention of Torture and Inhuman or Degrading Treatment or Punishment. CPT/Inf/E (2002) 1 - Rev. 2006. www.cpt.coe.int/en/docsstandards.htm (accessed 1 April 2008).

European Committee for the Prevention of Torture and Inhuman or Degrading Treatment or Punishment (CPT). 2008. Website. "States: Documents and Visits.” European Committee for the Prevention of Torture and Inhuman or Degrading Treatment or Punishment. http://www.cpt.coe.int/en/states.htm (accessed 7 October 2008).

European Convention on Human Rights. 1950. Council of Europe. Rome 4 November 1950 and its Five Protocols. http://www.hri.org/docs/ECHR50.html (accessed 28 October 2008).

European Convention for the Prevention of Torture and Inhuman or Degrading Treatment or Punishment. 1987. European Committee for the Prevention of Torture and Inhuman or Degrading Treatment or Punishment. CPT/Inf/C (2002) 1 [EN] (Part 1) - Strasbourg, 26.XI.1987. http://www.cpt.coe.int/en/documents/ecpt.htm (accessed 24 October 2008).

European Court of Human Rights. www.echr.coe.int/echr/ (accessed 11 April 2008).

European Court of Human Rights. 2008. Website. “Historical Background.” European Court of Human Rights.

http://www.echr.coe.int/ECHR/EN/Header/The+Court/The+Court/History+of+the+Court/ (accessed September 22, 2008).

European Union Council. 2003. "Directive on Minimum Standards for the Reception of Asylum Seekers: Directive 2003/9/EC of 27 January 2003.” Official Journal of the European Union, 6 February 2003.

http://ec.europa.eu/commission_barroso/frattini/archive/DIR_2003_9_EC.pdf (accessed 24 October 2008).

European Union Council. 2005. "Directive on Minimum Standards on Procedures in Member States for granting and Withdrawing Refugee Status: Directive 2005/85/EC of 1 December 2005.” Official Journal of the European Union, 13 December 2005, http://eurlex.europa.eu/LexUriServ/LexUriServ.do?uri=OJ:L:2005:326:0013:0034:EN:PDF (accessed 24 October 2008).

European Union Council. 2008. “Common Standards and Procedures in Member States for Returning Illegally Staying Third-Country Nationals.”

http://www.europarl.europa.eu/sides/getDoc.do?type=TA\&language=EN\&reference=P6-TA2008-0293 (accessed 11 November 2008).

Field, Ophelia. 2006. “Alternatives to Detention of Asylum Seekers and Refugees.” UN High Commissioner for Refugees. Legal and Protection Policy Research Series: POLAS/2006/03. April 2006. http://www.unhcr.org/refworld/docid/4472e8b84.html (accessed 2 October 2008). 
Flynn, Michael, and Cecilia Cannon. 2009. "The Privatization of Immigration Detention: Towards a Global View." Global Detention Project. September 2009. Geneva, Switzerland. http://www.globaldetentionproject.org/fileadmin/docs/GDP_PrivatizationPaper_Final5.pdf

Global Rights. 2004. "Using the Inter-American Human Rights System: a Guide for NGOs.” Global Rights. March 2004. www.globalrights.org/site/DocServer/ENGLISH__REVISED_7-19.pdf (accessed 8 April 2008).

Haitian Boat People (United States of America). 1997. Inter-American Commission on Human Rights. Merits Report N 51/96, Case 10.675. March 13, 1997.

http://www.cidh.org/annualrep/96eng/USA10675.htm (accessed 2 October 2008).

Human Rights in the Administration of Justice. 1971. UN General Assembly. Resolution 2858. Resolutions Adopted by the General Assembly during its Twenty-sixth Session. http://www.un.org/documents/ga/res/26/ares26.htm (accessed 21 October 2008).

Human Rights Committee. 1982. "CCPR General Comment No. 08: Right to liberty and security of persons (Art. 9)." UN Office of the High Commissioner for Human Rights. 30 June 1982. www2.ohchr.org/english/bodies/hrc/comments.htm (accessed 15 April 2008).

Human Rights Committee.1998. “Concluding Observations: Japan.” UN Office of the High Commissioner for Human Rights. CCPR/C/79/Add.102. 19 November 1998. tb.ohchr.org/default.aspx (accessed 15 April 2008).

Human Rights Committee. 1999. "General Comment No. 27: Freedom of movement (Art.12).” UN Office of the High Commissioner for Human Rights. CCPR/C/21/Rev.1/Add.9. 1 November 1999. www2.ohchr.org/english/bodies/hrc/comments.htm (accessed 15 April 2008).

Human Rights Committee. 2006. "Concluding Observations: Italy.” UN Office of the High Commissioner for Human Rights. CCPR/C/ITA/CO/5. 24 April 2006.

tb.ohchr.org/default.aspx (accessed 15 April 2008).

Human Rights of Migrants. 1999. Special Rapporteur on the Trafficking in Persons, Especially Women and Children, UN High Commissioner for Human Rights. Commission on Human Rights Resolution 1999/44.

http://www.unhchr.ch/Huridocda/Huridoca.nsf/TestFrame/134ef623dad1ad10802567630058 34fb?Opendocument (accessed 22 October 2008).

Inter-American Commission on Human Rights. 2008. Website. www.cidh.org (accessed 11 April 2008).

Inter-American Commission on Human Rights. 2008. "Special Rapporteurship on Migrant Workers and their Families.” Inter-American Commission on Human Rights. http://www.cidh.org/Migrantes/defaultmigrants.htm. (accessed 2 October 2008).

Inter-American Court of Human Rights. 1999. “Advisory Opinion OC-16/99, the Right to Information on Consular Assistance in the Framework of the Guarantees of the Due Process of Law.” Series A No. 16. October 1, 1999. www.corteidh.or.cr/opiniones.cfm (accessed 15 April 2008). 
Inter-American Court of Human Rights. 2003. "Advisory Opinion OC-18 Juridical Condition and Rights of the Undocumented Migrants.” Series A No. 18. September 17, 2003.

www.corteidh.or.cr/opiniones.cfm (accessed 15 April 2008).

Inter-American Democratic Charter. 2001. Organisation of American States (OAS). Adopted 11 September 2001.

http://mfa.gov.bz/library/treaties/Inter\%20American\%20Democratic\%20Charter.pdf (accessed 24 October 2008).

International Commission of Jurists (ICJ). 2005. "ICJ Memorandum on International Legal Framework on Administrative Detention and Counter Terrorism.” International Commission of Jurists. December 2005. www.icj.org/IMG/pdf/Administrative_detent_78BDB.pdf (accessed 15 April 2008).

International Committee of the Red Cross (ICRC). 1977. "Protocol Additional to the Geneva Conventions of 12 August 1949, and relating to the Protection of Victims of International Armed Conflicts (Protocol I), 8 June 1977. Commentaries: Part IV : Civilian population: Section III -- Treatment of persons in the power of a party to the conflict: Chapter I -- Field of application and protection of persons and objects.” ICRC. 8 June 1977. http://www.icrc.org/ihl.nsf/COM/470-750096?OpenDocument (accessed24 October 2009).

International Convention on the Elimination of All Forms of Racial Discrimination (ICERD). 1965. UN Office of the High Commissioner for Human Rights. Adopted and opened for signature and ratification 21 December 1965. http://www2.ohchr.org/english/law/cerd.htm (accessed 20 October 2008).

International Covenant on Civil and Political Rights (ICCPR). 1966. UN Office for the High Commissioner for Human Rights. Adopted by General Assembly resolution 2200A (XXI), 16 December 1966. Entry into force 23 March 1976.

http://www.unhchr.ch/html/menu3/b/a_ccpr.htm (accessed 20 October 2008)

International Convention on the Protection of the Rights of All Migrant Workers and Members of Their Families. 1990. UN Office for the High Commissioner for Human Rights. Adopted by General Assembly resolution 45/158 18 December 1990. http://www.unhchr.ch/html/menu3/b/m_mwctoc.htm (accessed 20 October 2008).

International Labor Organization (ILO). 2005. REPORT OF THE DIRECTOR-GENERAL: A global alliance against forced labour: Global Report under the Follow-up to the ILO Declaration on Fundamental Principles and Rights at Work: International Labour Conference: Report I (B).. International Labor Office. Geneva, Switzerland. 2005. http://www.unhcr.org/refworld/publisher,ILO,,,4289f7254,0.html (accessed 25 October 2009).

Jaquemet, Stephane. 2001. "The Cross-fertilization of International Humanitarian Law and Refugee Law.” IRRC, Vol 83, No. 843. September 2001.

Jesuit Refugee Service. “Detention in Europe.” Jesuit Refugee Service. www.detention-ineurope.org (accessed 1 October 2008).

Jesuit Refugee Service-Europe. 2007. “JRS' Memorandum for Portugal's European Union Presidency (July-December 2007) about the EU Directive on Return.” 2007. 
www.jrseurope.org/news_releases/JRS\%20Memorandum\%20to\%20the\%20Portuguese\%20P residency1.pdf (accessed 3 April, 2008).

Lyons, Scott. 2006. “The African Court on Human and Peoples' Rights.” American Society of International Law. Electronic Publications: ASIL Insights. Volume 10, Issue 24, September 2006. http://www.asil.org/insights060919.cfm (accessed 14 April 2008).

Marks, Susan, and Andrew Clapham. 2005. International Human Rights Lexicon. Oxford University Press. New York: 2005.

Mole, Nuala. 2002. "Asylum and the European Convention on Human Rights.” Council of Europe. Strasbourg H/Inf (2002) 9. Originally published as No. 9 of the "Human rights files" series by Council of Europe Publishing, 1984, 1987, 2000.

www.coe.int/T/E/Human_rights/h-inf(2002)9eng.pdf (accessed 3 April, 2008).

Organization of American States (OAS) Permanent Council. 2008. "OAS Action on the European Union's Returns Directive on Migration Issues.” Organization of American States. Resolution CP/RES.938 (1654/08). Approved by the Permanent Council 26 June 2008. http://www.oas.org/consejo/resolutions/res938.asp (accessed 24 October 2008).

Optional Protocol to the Convention on the Rights of the Child on the Sale of Children, Child Prostitution and Child Pornography (OPCRC). 2000. UN Office for the High Commissioner for Human Rights. Adopted by General Assembly resolution A/RES/54/263, 25 May 2000 entered into force on 18 January 2002. http://www2.ohchr.org/english/law/crc-sale.htm (accessed 28 October 2008).

Optional Protocol to the Convention against Torture and other Cruel, Inhuman or Degrading Treatment or Punishment. 2002. UN Office for the High Commissioner for Human Rights. Adopted 18 December 2002 by the UN General Assembly resolution A/RES/57/199. Entered into force 22 June 2006. http://www2.ohchr.org/english/law/cat-one.htm (accessed 20 October 2008).

Pejic, Jelena. 2005. "Procedural principles and safeguards for internment/administrative detention in armed conflict and other situations of violence.” International Review of the Red Cross, Volume 87 Number 858, pp. 375-391. June 2005. ICRC Publication 2006 ref. 0892. www.icrc.org/Web/Eng/siteeng0.nsf/htmlall/p0892/\$File/ICRC_002_0892.PDF!Open (accessed 15 April 2008).

Principios y Buenas Prácticas sobre la Protección de las Personas Privadas de Libertad en las Américas. 2008. Inter-American Commission on Human Rights. Resolución 1/08, CIDHOEA, 2008. Accessed at Association for the Prevention of Torture.

www.apt.ch/region/americas/CIDH_Principios.pdf (accessed 10 April 2008).

Protocol No. 11 to the Convention for the Protection of Human Rights and Fundamental Freedoms, restructuring the control machinery established thereby. 1994. Council of Europe. Strasbourg, 11.V.1994. http://conventions.coe.int/treaty/EN/Treaties/html/155.htm (accessed 24 October 2008).

Protocol to the African Charter on Human and Peoples' Rights on the Establishment of an African Court on Human and Peoples' Rights. 1998. African Commission on Human and 
Peoples’ Rights. Adopted June 1998, entered into force 2004.

http://www.achpr.org/english/_info/court_en.html (accessed 24 October 2008).

Protocol against the Smuggling of Migrants by Land, Sea and Air. 2000. UN High

Commissioner for Refugees. Adopted by the UN General Assembly 15 November 2000, supplementing the UN Convention against Transnational Organized Crime.

http://www.unhcr.org/cgi-bin/texis/vtx/refworld/rwmain?docid=479dee062 (accessed 21 October 2008).

Protocol to Prevent, Suppress, and Punish Trafficking in Persons, Especially Women and Children supplementing the United Nations Convention against Transnational Organized Crime. 2000. UN Office of the High Commissioner for Human Rights. Adopted and opened for signature, ratification and accession by General Assembly resolution 55/25 of 15 November 2000. http://www2.ohchr.org/english/law/protocoltraffic.htm (accessed 21 October 2008).

Protocol relating to the Status of Refugees. 1967. UN High Commissioner for Refugees. 1967. http://www.unhcr.org/cgi-bin/texis/vtx/protect?id=3c0762ea4 (accessed 20 October 2008).

Rafael Ferrer-Mazorra and other. $v$ the United States of America. 2001. Inter-American Commission on Human Rights. Admissibility and Merits Report N51/01, Case 9903. 4 April 2001. www.cidh.oas.org/annualrep/2000eng/ChapterIII/Merits/USA9903.htm (accessed 15 April 2008).

Saadi $v$ the United Kingdom. 2008. European Court of Human Rights. Judgment of 29 January 2008. cmiskp.echr.coe.int/tkp197/search.asp accessed 15 April 2008).

San José Declaration on Refugees and Internally Displaced Persons. 1994. Inter-American Commission on Human Rights.

Singh v. the United Kingdom. 1996. European Court of Human Rights. Judgment of 21 February 1996. Reports 1996-I. cmiskp.echr.coe.int/tkp197/search.asp (accessed April 15, 2008).

Shafiq v Australia. 2006. Human Rights Committee. Communication 1324/2004, Views of 31October 2006. http://tb.ohchr.org/default.aspx (access 2 October 2008).

Shams and others v Australia. 2007. Human Rights Committee. Communication No. 1255, 1256, 1259, 1260, 1266, 1268, 1270,1288/2004, Views of 20 July 2007. http://tb.ohchr.org/default.aspx (access 2 October 2008).

Special Rapporteur on the Human Rights of Migrants. 2008. Website. UN Office of the High Commissioner for Human Rights.

www2.ohchr.org/english/issues/migration/rapporteur/ (accessed 15 April 2008).

Special Rapporteur on the Human Rights of Migrants Ms. Gabriela Rodríguez Pizarro. 2002. "Specific Groups and Individuals: Migrant Workers." Report of the Special Rapporteur E/CN.4/2003/85, 30 December 2002. UN Office of the High Commissioner for Human Rights. 
www.unhchr.ch/Huridocda/Huridoca.nsf/0/3ff50c339f54a354c1256cde004bfbd8/\$FILE/G02 16255.doc (accessed March 14, 2008).

Special Rapporteur on the Human Rights of Migrants Ms. Gabriela Rodríguez Pizarro. 2004. "Report on Visit to Italy." UN Office of the High Commissioner for Human Rights. E/CN.4/2005/85/Add.3.15 November 2004. http://daccessdds.un.org/doc/UNDOC/GEN/G04/170/50/PDF/G0417050.pdf?OpenElement (accessed April 16, 2008).

Special Rapporteur on the Human Rights of Migrants Jorge Bustamante. 2008a. "Promotion and Protection of all Human Rights, Civil, Political, Economic, Social and Cultural Rights, Including the Right to Development." UN Office of the High Commissioner for Human Rights. A/HRC/7/12. 25 February 2008.

http://www2.ohchr.org/english/bodies/chr/special/sp_reportshrc_7th.htm (accessed 2 October 2008).

Special Rapporteur on the Human Rights of Migrants Jorge Bustamante. 2008b. "Promotion and Protection of all Human Rights, Civil, Political, Economic, Social and Cultural Rights, Including the Right to Development: Mission to the United States of America." UN Office of the High Commissioner for Human Rights. A/HRC/7/12/Add.2. 5 March 2008.

http://daccessdds.un.org/doc/UNDOC/GEN/G08/112/81/PDF/G0811281.pdf?OpenElement (accessed 2 October 2008).

Special Rapporteur on Prisons and Conditions of Detention in Africa. 2004. "Report on the Mission to the Republic of South Africa.” African Commission on Human and Peoples' Rights. June 2004.

www.achpr.org/english/Mission_reports/Special\%20Rap_Prisons_South\%20Africa.pdf (accessed 10 April 2008).

Special Rapporteur on the Sale of Children, Child Prostitution and Child Pornography. 2008. Website. UN Office of the High Commissioner for Human Rights.

http://www2.ohchr.org/english/issues/children/rapporteur/index.htm (accessed 24 September 2008).

Special Rapporteur on the Sale of Children, Child Prostitution and Child Pornography Juan Miguel Petit. 2003. "Rights of the Child: Mission to France, 25-29 November 2002.” UN Office of the High Commissioner for Human Rights. E/CN.4/2004/9/Add.1, 14 October 2003. http://www2.ohchr.org/english/issues/children/rapporteur/visits.htm (accessed 1 October 2008).

Special Rapporteur on the Sale of Children, Child Prostitution and Child Pornography Juan Miguel Petit. 2008. “Report on Visit to Mexico (May 2007).” UN Office of the High Commissioner for Human Rights. A/HRC/7/8/Add.2, 28 January 2008. http://www2.ohchr.org/english/issues/children/rapporteur/visits.htm (accessed 1 October 2008).

Special Rapporteur on Torture. 2008. Website. UN Office of the High Commissioner for Human Rights. www2.ohchr.org/english/issues/torture/rapporteur/ (accessed 15 April 2008).

Special Rapporteur on Torture. 2003. "Civil and Political Rights, Including the Questions of Torture and Detention: Report on Torture and other cruel, inhuman or degrading treatment or 
punishment.” UN Office of the High Commissioner for Human Rights. E/CN.4/2004/56, 23 December 2003.

http://daccessdds.un.org/doc/UNDOC/GEN/G03/173/27/PDF/G0317327.pdf?OpenElement (accessed on 2 May 2008).

Special Rapporteur on Torture. 2001. "Question of torture and other cruel, inhuman or degrading treatment or punishment.” UN General Assembly. GA A/56/156, 3 July 2001.

Special Rapporteur on Trafficking in Persons, Especially Women and Children. 2008. Website. UN Office of the High Commissioner for Human Rights. www2.ohchr.org/english/issues/trafficking/index.htm (accessed 15 April 2008)

Special Rapporteur on Trafficking in Persons, Especially Women and Children Sigma Huda. 2006. "Integration of the Human Rights of Women and a Gender Perspective: Report on the Mission to Lebanon 7 to 16 February 2005.” UN Office of the High Commissioner for Human Rights. E/CN.4/2006/62/Add.3. 20 February 2006. daccessdds.un.org/doc/UNDOC/GEN/G06/109/71/PDF/G0610971.pdf (accessed April 15, 2008).

Special Rapporteur on Violence against Women, its Causes and Consequences. 2008. Website. UN Office of the High Commissioner for Human Rights. http://www2.ohchr.org/english/issues/women/rapporteur/ (accessed 24 September 2008).

Special Rapporteur on Violence against Women, its Causes and Consequences Ms. Radhika Coomaraswamy. "Integration of the Human Rights of Women and the Gender Perspective: Violence Against Women.” UN Office of the High Commissioner for Human Rights. E/CN.4/2000/68. 29 February 2000. http://www2.ohchr.org/english/issues/women/rapporteur/annual.htm (accessed 30 September 2008).

Special Rapporteur on Violence against Women, its Causes and Consequences Yakin Ertürk. 2007. "Implementation of General Assembly Resolution 60/251 of 15 March 2006 Entitled "Human Rights Council": Mission to the Netherlands." UN Office of the High Commissioner for Human Rights. A/HRC/4/34/Add.4, 7 February 2007. http://daccessdds.un.org/doc/UNDOC/GEN/G07/106/89/PDF/G0710689.pdf?OpenElement (accessed 30 September 2008).

Standard Minimum Rules for the Treatment of Prisoners. 1955. UN Office of the High Commissioner for Human Rights. Adopted by the First United Nations Congress on the Prevention of Crime and the Treatment of Offenders, Geneva, 1955. Approved by Economic and Social Council in resolution 663 C (XXIV), 31 July 1957; and 2076 (LXII) of 13 May 1977. http://www.unhchr.ch/html/menu3/b/h_comp34.htm (accessed 21 October 2008).

UN Convention against Transnational Organized Crime and its Protocols. 2000. UN Office on Drugs and Crime. General Assembly resolution 55/25 of 15 November 2000.

http://www.unodc.org/unodc/en/treaties/CTOC/index.html (accessed 21 October 2008).

UN High Commissioner for Refugees Executive Committee. 1986. "Detention of Refugees and Asylum Seekers.” UN High Commissioner for Refugees. Conclusion No. 44 (XXXVII) 1986. http://www.unhcr.org/cgi- 
bin/texis/vtx/excom/opendoc.htm?tbl=EXCOM\&page=home\&id=3ae68c43c0 (accessed 2 October 2008).

UN High Commissioner for Refugees (UNHCR). 1994. "The Principle of Non-Refoulement as a Norm of Customary International Law. Response to the Questions Posed to UNHCR by the Federal Constitutional Court of the Federal Republic of Germany in Cases 2 BvR 1938/93, 2 BvR 1953/93, 2 BvR 1954/93.” UNHCR Refugee Policy and Practice. January 31, 1994. http://www.unhcr.org/publ/RSDLEGAL/437b6db64.html. (accessed 15 April 2008).

UN High Commissioner for Refugees (UNHCR). 1999. "Revised Guidelines on Applicable Criteria and Standards Relating to the Detention of Asylum Seekers.” UNHCR. February 1999. www.unhcr.org.au/pdfs/detentionguidelines.pdf (accessed April 15, 2008).

UN High Commissioner for Refugees (UNHCR). 2008. UNHCR Handbook for the Protection of Women and Girls. UNHCR. January 2008.

http://www.unhcr.org/protect/PROTECTION/47cfae612.html (accessed 2 October 2008).

UN Office of the High Commissioner for Human Rights (OHCHR). Undated. "Migration Discussion Paper on Administrative Detention.” UN Office of the High Commissioner for Human Rights. www2.ohchr.org/english/issues/migration/taskforce/disc-papers.htm (accessed 15 April 2008).

UN Office of the High Commissioner for Human Rights (OHCHR). 1994. "Resolution 1994/45: Question of Integrating the Rights of Women into the Human Rights Mechanisms of the United Nations and the Elimination of Violence against Women." UN Office of the High Commissioner for Human Rights.

http://www.unhchr.ch/Huridocda/Huridoca.nsf/TestFrame/401503e99f333b03802567360041 e65c?Opendocument (accessed 11 November 2008).

UN Office of the High Commissioner for Human Rights (OHCHR). 1990. "Resolution 1990/68: Sale of Children." UN Office of the High Commissioner for Human Rights. http://www2.ohchr.org/english/issues/children/rapporteur/docs/E.CN.4.RES.1990.68.E.pdf (accessed 11 November 2008).

UN Office of the High Commissioner for Human Rights (OHCHR). 2002. "Recommended Principles and Guidelines on Human Rights and Human Trafficking: Report of the United Nations High Commissioner for Human Rights to the Economic and Social Council." UN Office of the High Commissioner for Human Rights. E/2002/68/Add.1. 20 May 2002. www.unhchr.ch/huridocda/huridoca.nsf/e06a5300f90fa0238025668700518ca4/caf3deb2b05d 4f35c1256bf30051a003/\$FILE/N0240168.pdf (accessed 16 April 2008).

UN Press Release. 2008. "UN experts express concern about proposed EU Return Directive.” UN High Commissioner for Refugees. 18 July 2008.

http://www.unhchr.ch/huricane/huricane.nsf/view01/227C3A187C0BDB81C125748A0037A 405?opendocument (accessed 1 August 2008).

UN Refugee Convention (See also Convention Relating to the Status of Refugees). 1951. UN High Commissioner for Refugees. Geneva. http://www.unhcr.org/cgibin/texis/vtx/protect?id=3c0762ea4 (accessed 20 October 2008). 
UN Rules for the Protection of Juveniles Deprived of their Liberty. 1990. UN General Assembly, Adopted by General Assembly resolution 45/113of 14 December 1990, http://www.unhchr.ch/html/menu3/b/h_comp37.htm (accessed 21 October 2008).

Universal Declaration of Human Rights. 1948. UN Human Rights Committee. UN Department of Public Information. Adopted and proclaimed by the General Assembly resolution 217 A (III). 10 December 1948. http://www.unhchr.ch/udhr/ (accessed 20 October 2008).

Vienna Convention on Consular Relations. 1963. United Nations. Treaty Series, vo1. 596, p. 261. Vienna, 24 April 1963. Entered into force 19 March 1967.

http://untreaty.un.org/ilc/texts/instruments/english/conventions/9_2_1963.pdf (accessed 20

October 2008).

Webber, Frances. 2007. "Statewatch analysis: The original EU Directive on return (expulsion).” Statewatch.org. February 2007. http://www.statewatch.org/news/2007/apr/euexpulsion-sw-analysis-I.pdf (accessed 27 October 2008).

Working Group on Arbitrary Detention. 2008. Website. UN Office of the High Commissioner for Human Rights. www2.ohchr.org/english/issues/detention/index.htm (accessed 7 October 2008).

Working Group on Arbitrary Detention. 1991. "Resolution 1991/42.” UN Office of the High Commissioner for Human Rights. Cited in Yearbook of the United Nations 1991, page 554. http://books.google.ch/books?id=BTdmYFgvyi0C\&pg=PA615\&lpg=PA615\&dq=E/CN.4/19 91/42\&source=bl\&ots=hqWsDJVz6T\&sig=-

QTcPOLtMngnfgIiCXju43DnR8A\&hl=en\&sa=X\&oi=book_result\&resnum=1\&ct=result\#PP A553,M1 (accessed 11 November 2008).

Working Group on Arbitrary Detention. 1998. “Civil and Political Rights, Including Questions of Torture and Detention: Report of the Working Group on Arbitrary Detention.” UN Office of the High Commissioner for Human Rights. E/CN.4/1999/63. 18 December 1998.

http://daccessdds.un.org/doc/UNDOC/GEN/G98/052/52/PDF/G9805252.pdf?OpenElement (accessed 15 April 2008).

Working Group on Arbitrary Detention. 1999. “Civil and Political Rights, Including Questions of: Torture and Detention: Report of the Working Group on Arbitrary Detention: Annex II” UN Office of the High Commissioner for Human Rights. E/CN.4/2000/4, Annex II. 28 December 1999. http://ap.ohchr.org/documents/mainec.aspx (accessed 16 April 2008).

Working Group on Arbitrary Detention. 2008. "Promotion and Protection of all Human Rights, Civil, Political, Economic, Social and Cultural rights, Including the Right to Development: Report of the Working Group on Arbitrary Detention." UN Office of the High Commissioner for Human Rights. A/HRC/7/4. 10 January 2008. http://daccessdds.un.org/doc/UNDOC/GEN/G08/100/91/PDF/G0810091.pdf?OpenElement (accessed 16 April 2008). 


\section{Official Documents}

- Human Rights Council (Commission on Human Rights)

- General Comments by United Nations Treaty Bodies

- Views and Decisions by United Nations Treaty Bodies

- Observations and Recommendations by United Nations Treaty Bodies

- United Nations High Commissioner for Refugees

- Judgments by the European Court of Human Rights

- European Committee for the Prevention of Torture (CPT)

- European Union Directives

- Judgments and Advisory Opinions of the Inter-American Court of Human Rights

- Inter-American Commission on Human Rights

- Decisions of the Inter-American Commission on Human Rights

- Documents by the African Commission on Human and Peoples’ Rights

\section{Human Rights Council (Commission on Human Rights)}

Body of Principles for the Protection of All Persons under Any Form of Detention or Imprisonment. 1988. UN General Assembly. Adopted by General Assembly resolution 43/173. 9 December 1988. http://www.unhchr.ch/html/menu3/b/h_comp36.htm (accessed 21 October 2008).

Commission on Human Rights resolution 1997/50. Question of Arbitrary Detention. Adopted 15 April 1997.

Declaration on the Human Rights of Individuals Who are not Nationals of the Country in which They Live (DHRINNC). 1985. UN General Assembly. Adopted by General Assembly resolution 40/144 of 13 December 1985. http://www.unhchr.ch/html/menu3/b/o_nonnat.htm (accessed 21 October 2008).

Special Rapporteur on the Human Rights of Migrants. 2008. Website. UN Office of the High Commissioner for Human Rights. www2.ohchr.org/english/issues/migration/rapporteur/ (accessed 15 April 2008).

Special Rapporteur on the Human Rights of Migrants Ms. Gabriela Rodríguez Pizarro. 2002. "Specific Groups and Individuals: Migrant Workers." Report of the Special Rapporteur E/CN.4/2003/85, 30 December 2002. UN Office of the High Commissioner for Human Rights.

www.unhchr.ch/Huridocda/Huridoca.nsf/0/3ff50c339f54a354c1256cde004bfbd8/\$FILE/G02 16255.doc (accessed March 14, 2008).

Special Rapporteur on the Human Rights of Migrants Ms. Gabriela Rodríguez Pizarro. 2004. "Report on Visit to Italy." UN Office of the High Commissioner for Human Rights. E/CN.4/2005/85/Add.3.15 November 2004. http://daccessdds.un.org/doc/UNDOC/GEN/G04/170/50/PDF/G0417050.pdf?OpenElement (accessed April 16, 2008).

Special Rapporteur on the Human Rights of Migrants Jorge Bustamante. 2008a. "Promotion and Protection of all Human Rights, Civil, Political, Economic, Social and Cultural Rights, 
Including the Right to Development." UN Office of the High Commissioner for Human Rights. A/HRC/7/12. 25 February 2008.

http://www2.ohchr.org/english/bodies/chr/special/sp_reportshrc_7th.htm (accessed 2 October 2008).

Special Rapporteur on the Human Rights of Migrants Jorge Bustamante. 2008b. "Promotion and Protection of all Human Rights, Civil, Political, Economic, Social and Cultural Rights, Including the Right to Development: Mission to the United States of America." UN Office of the High Commissioner for Human Rights. A/HRC/7/12/Add.2. 5 March 2008. http://daccessdds.un.org/doc/UNDOC/GEN/G08/112/81/PDF/G0811281.pdf?OpenElement (accessed 2 October 2008).

Special Rapporteur on the Sale of Children, Child Prostitution and Child Pornography. 2008. Website. UN Office of the High Commissioner for Human Rights.

http://www2.ohchr.org/english/issues/children/rapporteur/index.htm (accessed 24 September 2008).

Special Rapporteur on the Sale of Children, Child Prostitution and Child Pornography Juan Miguel Petit. 2003. "Rights of the Child: Mission to France, 25-29 November 2002." UN Office of the High Commissioner for Human Rights. E/CN.4/2004/9/Add.1, 14 October 2003. http://www2.ohchr.org/english/issues/children/rapporteur/visits.htm (accessed 1 October 2008).

Special Rapporteur on the Sale of Children, Child Prostitution and Child Pornography Juan Miguel Petit. 2008. "Report on Visit to Mexico (May 2007)." UN Office of the High Commissioner for Human Rights. A/HRC/7/8/Add.2, 28 January 2008. http://www2.ohchr.org/english/issues/children/rapporteur/visits.htm (accessed 1 October 2008).

Special Rapporteur on Torture and Other Cruel, Inhuman or Degrading Treatment or Punishment. 2008. Website. UN Office of the High Commissioner for Human Rights. www2.ohchr.org/english/issues/torture/rapporteur/ (accessed 15 April 2008).

Special Rapporteur on Torture, Report of the Special Rapporteur Theo van Boven. 2003. "Civil and Political Rights, Including the Questions of Torture and Detention: Report on Torture and other cruel, inhuman or degrading treatment or punishment." UN Office of the High Commissioner for Human Rights. E/CN.4/2004/56, 23 December 2003. http://daccessdds.un.org/doc/UNDOC/GEN/G03/173/27/PDF/G0317327.pdf?OpenElement (accessed on 2 May 2008).

Special Rapporteur on Torture. 1985. “Commission Resolution 1985/33”. UN Office of the High Commissioner for Human Rights.

http://ap.ohchr.org/documents/E/CHR/resolutions/E_CN.4_RES_1985_33.pdf (accessed 22 October 2008).

Special Rapporteur on Trafficking in Persons, Especially Women and Children. 2008. Website. UN Office of the High Commissioner for Human Rights.

www2.ohchr.org/english/issues/trafficking/index.htm (accessed 15 April 2008)

Special Rapporteur on Trafficking in Persons, Especially Women and Children Sigma Huda. 2006. “ Integration of the Human Rights of Women and a Gender Perspective: Report on the 
Mission to Lebanon 7 to 16 February 2005." UN Office of the High Commissioner for Human Rights. E/CN.4/2006/62/Add.3. 20 February 2006.

daccessdds.un.org/doc/UNDOC/GEN/G06/109/71/PDF/G0610971.pdf (accessed April 15, 2008).

Special Rapporteur on Violence against Women, its Causes and Consequences. 2008. Website. UN Office of the High Commissioner for Human Rights.

http://www2.ohchr.org/english/issues/women/rapporteur/ (accessed 24 September 2008).

Special Rapporteur on Violence against Women, its Causes and Consequences Ms. Radhika Coomaraswamy. "Integration of the Human Rights of Women and the Gender Perspective: Violence Against Women.” UN Office of the High Commissioner for Human Rights. E/CN.4/2000/68. 29 February 2000. http://www2.ohchr.org/english/issues/women/rapporteur/annual.htm (accessed 30 September 2008).

Special Rapporteur on Violence against Women, its Causes and Consequences Yakin Ertürk. 2007. "Implementation of General Assembly Resolution 60/251 of 15 March 2006 Entitled "Human Rights Council": Mission to the Netherlands." UN Office of the High Commissioner for Human Rights. A/HRC/4/34/Add.4, 7 February 2007.

http://daccessdds.un.org/doc/UNDOC/GEN/G07/106/89/PDF/G0710689.pdf?OpenElement (accessed 30 September 2008).

UN Rules for the Protection of Juveniles Deprived of their Liberty. 1990. UN General Assembly, Adopted by General Assembly resolution 45/113of 14 December 1990, http://www.unhchr.ch/html/menu3/b/h_comp37.htm (accessed 21 October 2008).

Working Group on Arbitrary Detention. 2008. Website. UN Office of the High Commissioner for Human Rights. www2.ohchr.org/english/issues/detention/index.htm (accessed 7 October 2008).

Working Group on Arbitrary Detention. 1991. "Resolution 1991/42.” UN Office of the High Commissioner for Human Rights. Cited in Yearbook of the United Nations 1991, page 554. http://books.google.ch/books?id=BTdmYFgvyi0C\&pg=PA615\&lpg=PA615\&dq=E/CN.4/19 91/42\&source=bl\&ots=hqWsDJVz6T\&sig=-

QTcPOLtMngnfgIiCXju43DnR8A\&hl=en\&sa=X\&oi=book_result\&resnum=1\&ct=result\#PP A553,M1 (accessed 11 November 2008).

Working Group on Arbitrary Detention. 1998. “Civil and Political Rights, Including Questions of Torture and Detention: Report of the Working Group on Arbitrary Detention.” UN Office of the High Commissioner for Human Rights. E/CN.4/1999/63. 18 December 1998.

http://daccessdds.un.org/doc/UNDOC/GEN/G98/052/52/PDF/G9805252.pdf?OpenElement (accessed 15 April 2008).

Working Group on Arbitrary Detention. 1999. “Civil and Political Rights, Including Questions of: Torture and Detention: Report of the Working Group on Arbitrary Detention: Annex II" UN Office of the High Commissioner for Human Rights. E/CN.4/2000/4, Annex II. 28 December 1999. http://ap.ohchr.org/documents/mainec.aspx (accessed 16 April 2008). 
Working Group on Arbitrary Detention. 2008. "Promotion and Protection of all Human Rights, Civil, Political, Economic, Social and Cultural rights, Including the Right to Development: Report of the Working Group on Arbitrary Detention." UN Office of the High Commissioner for Human Rights. A/HRC/7/4. 10 January 2008.

http://daccessdds.un.org/doc/UNDOC/GEN/G08/100/91/PDF/G0810091.pdf?OpenElement (accessed 16 April 2008).

\section{General Comments by United Nations Treaty Bodies}

Committee on the Elimination of Racial Discrimination (CERD). 2004. "General

Recommendation No.30: Discrimination Against Non Citizens (General Comments).” UN

Office of the High Commissioner for Human Rights. 1 October 2004.

www.unhchr.ch/tbs/doc.nsf/(Symbol)/e3980a673769e229c1256f8d0057cd3d (accessed 15

April 2008).

Committee on the Rights of the Child (CRC). 2005a. "General Comment No 6, The Treatment of Unaccompanied and Separated Children Outside their Country of Origin.” UN Office of the High Commissioner for Human Rights. CRC/GC/2005/6. 1 September 2005. www2.ohchr.org/english/bodies/crc/comments.htm (accessed 15 April 2008).

Human Rights Committee. 1999., "General Comment No. 27: Freedom of movement (Art.12).” , UN Office of the High Commissioner for Human Rights.

CCPR/C/21/Rev.1/Add.9,. 21 November 1999.

www2.ohchr.org/english/bodies/hrc/comments.htm (accessed 15 April 2008).

Human Rights Committee. 1982. "CCPR General Comment No. 08: Right to liberty and security of persons (Art. 9).” UN Office of the High Commissioner for Human Rights. 30 June 1982. www2.ohchr.org/english/bodies/hrc/comments.htm (accessed 15 April 2008).

\section{Views and Decisions by United Nations Treaty Bodies}

A. v. Australia. 1997. Human Rights Committee. Communication No. 560/1993, Views of 3 April 1997. http://tb.ohchr.org/default.aspx (accessed 2 October 2008).

Bakhtiyari v. Australia. 2003. Human Rights Committee. Communication No.1069/2002, Views of 29 October 2003. http://tb.ohchr.org/default.aspx (access 2 October 2008).

C v Australia. 2002. Human Rights Committee. Communication No. 900/1999, Views of 28 October 2002. http://tb.ohchr.org/default.aspx (access 2 October 2008).

Celepli v. Sweden. 1994. Human Rights Committee. Communication No. 456/1991, Views of 18 July 1994. http://tb.ohchr.org/default.aspx (access 2 October 2008).

Shafiq v Australia. 2006. Human Rights Committee. Communication 1324/2004, Views of 31October 2006. http://tb.ohchr.org/default.aspx (access 2 October 2008).

Shams and others v Australia. 2007. Human Rights Committee. Communication No. 1255, 1256, 1259, 1260, 1266, 1268, 1270,1288/2004, Views of 20 July 2007. http://tb.ohchr.org/default.aspx (access 2 October 2008). 


\section{Observations and Recommendations by United Nations Treaty Bodies}

Committee Against Torture. 2006. "Concluding Observations: France.” UN Office of the High Commissioner for Human Rights. CAT/C/FRA/CO/3. 3 April 2006.

tb.ohchr.org/default.aspx (accessed 15 April 2008).

Committee Against Torture. 2007a. "Concluding Observations: Japan.” UN Office of the High Commissioner for Human Rights. CAT/C/JPN/CO/1, 3 August 2007.

tb.ohchr.org/default.aspx (accessed 15 April 2008).

Committee Against Torture. 2007b. "Concluding Observations: Ukraine.” UN Office of the High Commissioner for Human Rights. CAT/C/UKR/CO/5. 3 August 2007.

tb.ohchr.org/default.aspx (accessed 15 April 2008).

Committee on Migrant Workers. 2006. “Concluding Observations: Mexico.” UN Office of the High Commissioner for Human Rights. CMW/C/MEX/CO/1. 20 December 2006.

tb.ohchr.org/default.aspx (accessed 15 April 2008).

Committee on the Elimination of Discrimination Against Women. 2006. "Concluding Comments: Malaysia.” UN Office of the High Commissioner for Human Rights.

CEDAW/C/MYS/CO/2. 31 May 2006. tb.ohchr.org/default.aspx (accessed April 15, 2008).

Committee on the Rights of the Child (CRC). 2005b. "Concluding Observations: Australia." CRC/C/15/Add.268. UN Office of the High Commissioner for Human Rights. 20 October 2005. tb.ohchr.org/default.aspx (accessed 15 April 2008).

Convention on the Rights of the Child. 1989. Committee on the Rights of the Child, UN Office for the High Commissioner for Human Rights. Adopted by General Assembly resolution 44/25. 20 November 1989. Entry into force 2 September 1990. http://www.unhchr.ch/html/menu3/b/k2crc.htm (accessed 20 October 2008).

Committee on the Rights of the Child (CRC). 2005a. "General Comment $\mathrm{N}^{\circ}$ 6, The Treatment of Unaccompanied and Separated Children Outside their Country of Origin." UN Office of the High Commissioner for Human Rights. CRC/GC/2005/6. 1 September 2005. www2.ohchr.org/english/bodies/crc/comments.htm (accessed 15 April 2008).

Committee on the Rights of the Child (CRC). 2007. "Concluding Observations on the Report Submitted under the Optional Protocol to the Convention on the Rights of the Child on the Sale of Children, Child Prostitution and Child Pornography (OPSC): France.” UN Office of the High Commissioner for Human Rights. CRC/C/OPSC/FRA/CO/1. 15 October 2007. tb.ohchr.org/default.aspx (accessed 15 April 2008).

Human Rights Committee.1998. “Concluding Observations: Japan.” UN Office of the High Commissioner for Human Rights. CCPR/C/79/Add.102. 19 November 1998. tb.ohchr.org/default.aspx (accessed 15 April 2008).

Human Rights Committee. 2006. "Concluding Observations: Italy.” UN Office of the High Commissioner for Human Rights. CCPR/C/ITA/CO/5. 24 April 2006.

tb.ohchr.org/default.aspx (accessed 15 April 2008). 


\section{United Nation High Commissioner for Refugees}

UN High Commissioner for Refugees Executive Committee. 1986. "Detention of Refugees and Asylum Seekers.” UN High Commissioner for Refugees. Conclusion No. 44 (XXXVII) 1986. http://www.unhcr.org/cgi-

bin/texis/vtx/excom/opendoc.htm?tbl=EXCOM\&page=home\&id=3ae68c43c0 (accessed 2 October 2008).

UN High Commissioner for Refugees (UNHCR). 1994. "The Principle of Non-Refoulement as a Norm of Customary International Law. Response to the Questions Posed to UNHCR by the Federal Constitutional Court of the Federal Republic of Germany in Cases 2 BvR 1938/93, 2 BvR 1953/93, 2 BvR 1954/93.” UNHCR Refugee Policy and Practice. January 31, 1994. http://www.unhcr.org/publ/RSDLEGAL/437b6db64.html. (accessed 15 April 2008).

UN High Commissioner for Refugees (UNHCR). 1999. "Revised Guidelines on Applicable Criteria and Standards Relating to the Detention of Asylum Seekers.” UNHCR. February 1999. www.unhcr.org.au/pdfs/detentionguidelines.pdf (accessed April 15, 2008).

\section{Judgments by the European Court of Human Rights}

Amuur v France. 1996. European Court of Human Rights. Judgment of 25 June 1996. Reports 1996-III. cmiskp.echr.coe.int/tkp197/search.asp (accessed 15 April 2008).

Benjamin and Wilson v United Kingdom. 2002. European Court of Human Rights., judgment of 26 September 2002. cmiskp.echr.coe.int/tkp197/search.asp (accessed 15 April 2008).

Chahal v. the United Kingdom. 1996. European Court of Human Rights. Judgment of 15 November 1996. Reports 1996-V. cmiskp.echr.coe.int/tkp197/search.asp (accessed 15 April 2008).

De Wilde, Ooms and Versyp v. Belgium. 1971. European Court of Human Rights. Judgment of 18 June 1971. Series A no. 12. cmiskp.echr.coe.int/tkp197/search.asp (accessed 15 April 2008).

European Court of Human Rights. www.echr.coe.int/echr/ (accessed 11 April 2008).

Singh v. the United Kingdom. 1996. European Court of Human Rights. Judgment of 21 February 1996. Reports 1996-I. cmiskp.echr.coe.int/tkp197/search.asp (accessed April 15, 2008).

Saadi $v$ the United Kingdom. 2008. European Court of Human Rights. Judgment of 29 January 2008. cmiskp.echr.coe.int/tkp197/search.asp accessed 15 April 2008).

European Committee for the Prevention of Torture and Inhuman or Degrading Treatment or Punishment (CPT). 2008. Website. www.cpt.coe.int/en/about.htm (accessed 1 April 2008).

European Committee for the Prevention of Torture and Inhuman or Degrading Treatment or Punishment (CPT). 2002. “CPT Standards.” European Committee for the Prevention of 
Torture and Inhuman or Degrading Treatment or Punishment. CPT/Inf/E (2002) 1 - Rev. 2006. www.cpt.coe.int/en/docsstandards.htm (accessed 1 April 2008).

\section{European Union Directives}

European Union Council. 2003. "Directive on Minimum Standards for the Reception of Asylum Seekers: Directive 2003/9/EC of 27 January 2003.” Official Journal of the European Union, 6 February 2003. http://ec.europa.eu/commission_barroso/frattini/archive/DIR_2003_9_EC.pdf (accessed 24 October 2008).

European Union Council. 2005. "Directive on Minimum Standards on Procedures in Member States for granting and Withdrawing Refugee Status: Directive 2005/85/EC of 1 December 2005." Official Journal of the European Union, 13 December 2005, http://eurlex.europa.eu/LexUriServ/LexUriServ.do?uri=OJ:L:2005:326:0013:0034:EN:PDF (accessed 24 October 2008).

European Union Council. 2008. “Common Standards and Procedures in Member States for Returning Illegally Staying Third-Country Nationals.” http://www.europarl.europa.eu/sides/getDoc.do?type=TA\&language=EN\&reference=P6-TA2008-0293 (accessed 11 November 2008).

\section{Judgments and Advisory Opinions of the Inter-American Court of Human Right}

Inter-American Court of Human Rights. 1999. “Advisory Opinion OC-16/99, the Right to Information on Consular Assistance in the Framework of the Guarantees of the Due Process of Law." Series A No. 16. October 1, 1999. www.corteidh.or.cr/opiniones.cfm (accessed 15 April 2008).

Inter-American Court of Human Rights. 2003. “Advisory Opinion OC-18 Juridical Condition and Rights of the Undocumented Migrants.” Series A No. 18. September 17, 2003. www.corteidh.or.cr/opiniones.cfm (accessed 15 April 2008).

\section{Inter-American Commission on Human Rights}

Inter-American Commission on Human Rights. 2008. Website. www.cidh.org (accessed 11 April 2008).

Inter-American Commission on Human Rights. 2008. "Special Rapporteurship on Migrant Workers and their Families.” Inter-American Commission on Human Rights. http://www.cidh.org/Migrantes/defaultmigrants.htm. (accessed 2 October 2008).

Principios y Buenas Prácticas sobre la Protección de las Personas Privadas de Libertad en las Américas. 2008. Inter-American Commission on Human Rights. Resolución 1/08, CIDHOEA, 2008. Accessed at Association for the Prevention of Torture. www.apt.ch/region/americas/CIDH_Principios.pdf (accessed 10 April 2008). 


\section{Decisions of the Inter-American Commission on Human Rights}

Haitian Boat People (United States of America). 1997. Inter-American Commission on Human Rights. Merits Report N 51/96, Case 10.675. March 13, 1997.

http://www.cidh.org/annualrep/96eng/USA10675.htm (accessed 2 October 2008).

Rafael Ferrer-Mazorra and other. $v$ the United States of America. 2001. Inter-American Commission on Human Rights. Admissibility and Merits Report N51/01, Case 9903. 4 April 2001. www.cidh.oas.org/annualrep/2000eng/ChapterIII/Merits/USA9903.htm (accessed 15 April 2008).

\section{Documents by the African Commission on Human and Peoples’ Rights}

African Commission on Human and Peoples' Rights. www.achpr.org (accessed 11 April 2008).

Special Rapporteur on Prisons and Conditions of Detention in Africa. 2004. "Report on the Mission to the Republic of South Africa." African Commission on Human and Peoples' Rights. June 2004. www.achpr.org/english/Mission_reports/Special\%20Rap_Prisons_South\%20Africa.pdf (accessed 10 April 2008).

African Commission on Human and Peoples’ Rights. 1991-2007. "Final Communiqués and other Documentation of the African Commission on Human and Peoples' Rights (Sessions 1991-2007)." University of Minnesota Human Rights Library.

www1.umn.edu/humanrts/africa/communiques.html (accessed 14 April 2008). 